\title{
Crop-livestock integration beyond the farm level: a review
}

\author{
Guillaume Martin $^{1} \cdot$ Marc Moraine $^{1} \cdot$ Julie Ryschawy ${ }^{1} \cdot$ Marie-Angélina Magne $^{1} \cdot$ \\ Masayasu Asai $^{2} \cdot$ Jean-Pierre Sarthou $^{1} \cdot$ Michel Duru $^{1} \cdot$ Olivier Therond $^{1,3}$
}

Accepted: 3 August 2016 /Published online: 9 September 2016

(C) INRA and Springer-Verlag France 2016

\begin{abstract}
Paradoxically, the number of crop-livestock farms is declining across Europe, despite the fact that crop-livestock farms are theoretically optimal to improve the sustainability of agriculture. To solve this issue, crop-livestock integration may be organized beyond the farm level. For instance, local groups of farmers can negotiate land-use allocation patterns and exchange materials such as manure, grain, and straw. Development of such a collective agricultural system raises questions, rarely documented in the literature, about how to integrate crops and livestock among farms, and the consequences, impacts, and conditions of integrating them. Here, we review the different forms of crop-livestock integration beyond the farm level, their potential benefits, and the features of decision support systems (DSS) needed for the integration process. We identify three forms of crop-livestock integration beyond the farm level: local coexistence, complementarity, and synergy, each with increasingly stronger temporal, spatial, and organizational coordination among farms. We claim that the forms of integration implemented define the nature, area, and spatial configuration of crops, grasslands, and animals in farms and landscapes. In turn, these configurations influence the provision of ecosystem services. For instance, we show that the synergy form of integration promotes soil fertility,
\end{abstract}

Guillaume Martin and Marc Moraine contributed equally to this work.

Guillaume Martin

guillaume.martin@toulouse.inra.fr

1 AGIR, Université de Toulouse, INPT, INP-Purpan, INRA, Université Toulouse, ENFA, 31320 Auzeville, France

2 PRIMAFF, 3-1-1, Kasumigaseki, Chiyoda-ku, Tokyo 100-0013, Japan

3 UMR LAE, INRA, Université de Lorraine, 68000 Colmar, France erosion control, and field-level biological regulation services through organizational coordination among farmers and spatiotemporal integration between crops, grasslands, and animals. We found that social benefits of the synergy form of integration include collective empowerment of farmers. We claim that design of the complementarity and synergy forms of crop-livestock integration can best be supported by collective participatory workshops involving farmers, agricultural consultants, and researchers. In these workshops, spatialized simulation modeling of crop-livestock integration among farms is the basis for achieving the upscaling process involved in integrating beyond the farm level. Facilitators of these workshops have to pay attention to the consequences on governance and equity issues within farmers groups.

Keywords Mixed farm $\cdot$ Agroecology $\cdot$ Ecological intensification $\cdot$ Farming system design $\cdot$ Scaling $\cdot$ Farm model $\cdot$ Decision support system $\cdot$ Collaborative farming . Ecosystem services

\section{Contents}

1. Introduction

1.1. Integrated systems to improve the sustainability of agriculture

1.2. The decline in crop-livestock integration at the farm level: a lock-in effect?

1.3. Aims and scope of this review

2. Benefits and limits of crop-livestock integration beyond the farm level

2.1. Crop-livestock integration beyond the farm level: how?

2.2. Crop-livestock integration beyond the farm level to promote ecosystem services

2.2.1. Ecosystem services and agriculture 
2.2.2. Soil fertility services promoted by crop-livestock integration beyond the farm level

2.2.3. Biological regulation services promoted by crop-livestock integration beyond the farm level

2.3. Crop-livestock integration beyond the farm level to promote economic and social benefits

2.3.1. Economic benefits

2.3.2. Social benefits

2.4. Potential limitations of crop-livestock integration beyond the farm level

2.4.1. Cognitive and behavioral limitations

2.4.2. Environmental limitations

2.4.3. Economic limitations

2.4.4. Social limitations

3. Supporting the development of crop-livestock integration beyond the farm level

3.1. Motivations for using DSS to stimulate social learning and collective thinking

3.2. Required features of DSS for supporting the development of crop-livestock integration beyond the farm level

3.2.1. DSS requirements to support complementarity and synergy forms of crop-livestock integration

3.2.2. DSS function, behavior, and structure

3.2.3. Specific requirements of computer models

3.3. Related issues: a matter of upscaling

3.3.1. Upscaling processes involved

3.3.2. Outscaling

3.3.3. Spatial upscaling

3.3.4. Temporal upscaling

3.3.5. Upscaling from individual to collective decision-making

4. Conclusion

Acknowledgements

References

\section{Introduction}

\subsection{Integrated crop-livestock farms to improve the sustainability of agriculture}

Agriculture of the Northern hemisphere has long been driven by trends of specialization and intensification imposed by regulation, political, and economic constraints (Lemaire et al. 2014; Peyraud et al. 2014; Russelle et al. 2007; Sulc and Tracy 2007; Wilkins 2008). In specialized and intensive agricultural systems, management practices are standardized, and based on the use of technology such as synthetic inputs (e.g., pesticides and mineral fertilizers) and high-performance machinery. The available technology is mainly expected (i) to handle biophysical limits for agricultural production; (ii) to reduce the vulnerability of agricultural systems to external perturbations by artificializing agroecosystems, e.g., irrigation to supplement rainfall; and (iii) to reduce the workload of farmers. Today, environmental and social impacts (water pollution, food pollution, etc.) related to specialized and intensive agricultural systems (Horrigan et al. 2002) are no longer accepted by some members of society. As a response to these issues, several authors suggest developing more integrated forms of agriculture to restore the sustainability of agricultural systems (Bell and Moore 2012; Hendrickson et al. 2008; Russelle et al. 2007).

Diversified and (horizontally) integrated agricultural systems promote ecological interactions over space and time between system components (e.g., crops, grasslands, and animals) and create opportunities for synergistic resource transfers between them (Hendrickson et al. 2008; Kremen et al. 2012). They offer opportunities to substitute technologies (e.g., synthetic inputs) and high-performance machinery used in specialized and intensive agricultural systems with ecosystem services, such as soil fertility or biological regulation of pests and diseases (Duru et al. 2015; Horlings and Marsden 2011; Power 2010). In an agricultural context, ecosystem services are the products of interactions between farmland biodiversity (i.e., planned biodiversity — crops, animals, hedgerows, etc. - and associated biodiversity - soil flora and fauna, herbivores, etc. colonizing the farm; Altieri 1999) and adapted management practices that are integrated over different temporal and spatial scales (Altieri 1999; Kremen et al. 2012). While soil fertility can be managed at the field level through appropriate crop rotations, intercropping, and tillage practices, biological regulation of pests can be also managed at the landscape level due to the key role of crop spatial distribution, field margins, and hedges (Garbach et al. 2014; Gaba et al. 2014; Landis et al. 2000; Power 2010; Rusch et al. 2010).

\subsection{The decline in crop-livestock integration at the farm level: a lock-in effect?}

Crop-livestock systems (Fig. 1) are suggested as a theoretical ideal for implementing the principles of diversified and (horizontally) integrated agriculture (Hendrickson et al. 2008; Herrero et al. 2010; Lemaire et al. 2014; Ryschawy et al. 2014). Yet they have already declined in number in countries of the Northern hemisphere, and the trend towards specialization continues (Russelle et al. 2007; Peyraud et al. 2014; Veysset et al. 2014). To analyze this decline, two dynamics of specialization (i.e., a method of production involving few or only one cropping or livestock system; Bos and van de Ven 1999) must be assessed: specialization of crop production and of animal production implying abandonment of animal production and cash crop production, respectively (Billen et al. 2010). Specialization of crop production is increasing, 
Fig. 1 Diversified and integrated crop-livestock systems in Gascony, southwestern France, that incorporate crop fields, grasslands, grazing animals, hedgerows, and woodlots. The ecological and patrimonial value of such systems is threatened by agricultural specialization and intensification, resulting in abandonment of less productive areas and homogenization and simplification of land use in productive fields. (Credit: J.P. Sarthou, J. Ryschawy)
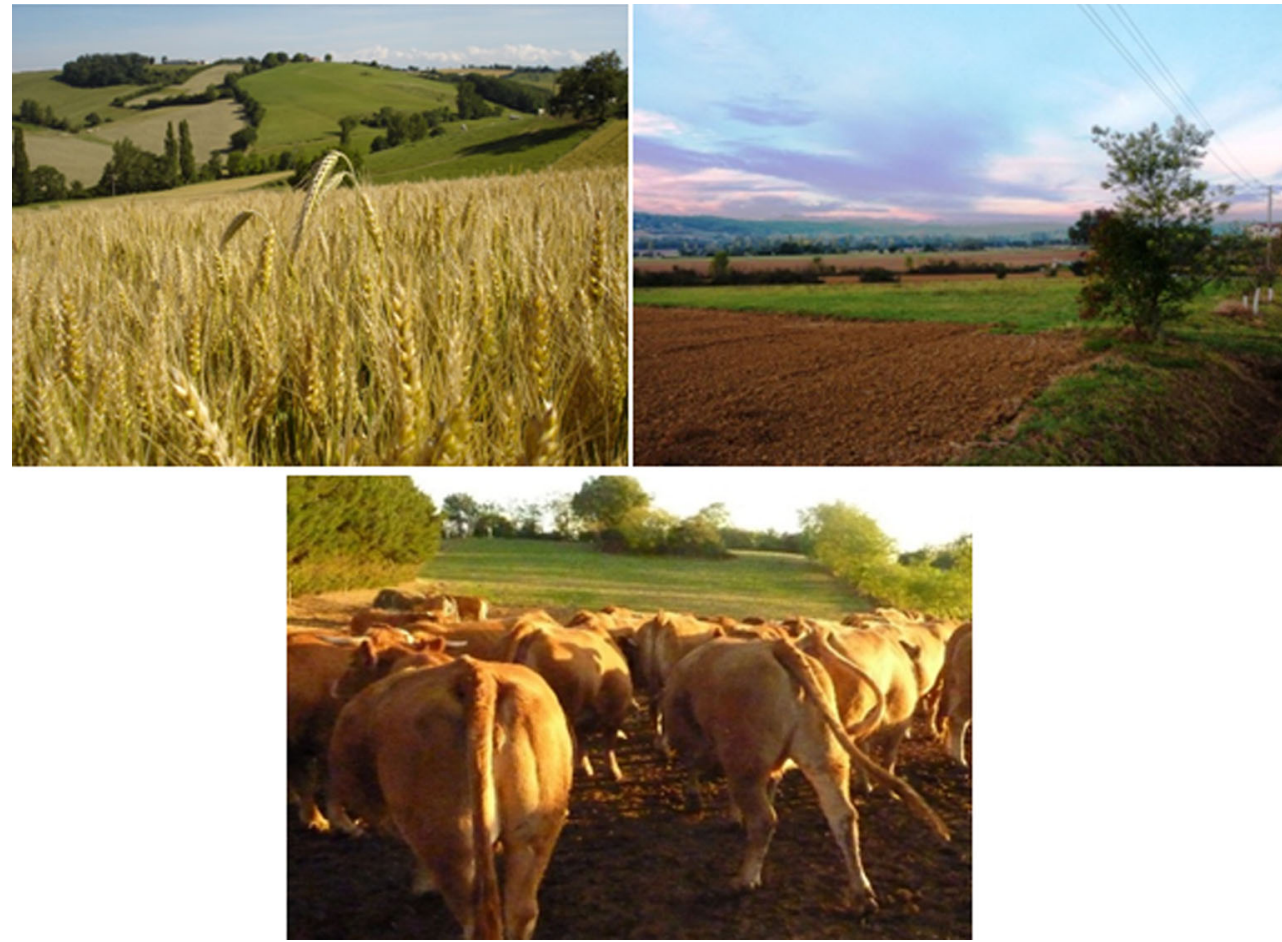

especially in areas dominated by large farm units (Peyraud et al. 2014). Integrated crop-livestock farmers abandon animal production for several reasons: (i) costs of energy and mineral fertilizer for specialized cereal cropping increase more slowly than costs of labor required for animal production (Peyraud et al. 2014); (ii) workload simplification and control (especially by eliminating milking and calving) (Bell and Moore 2012; Bell et al. 2014; Doole et al. 2009; Sulc and Tracy 2007); (iii) changing regulations, such as norms on livestock buildings, make upgrading farms prohibitively expensive (Peyraud et al. 2014); and (iv) disappearance of supply chains that process and sell animal products (e.g., concentration of milk industries in specialized regions, disappearance of small slaughterhouses) (Moraine et al. 2014).

Specialization of animal production occurs in areas dominated by small farm units where animal production was already the main agricultural activity and is expected to expand in Europe with the abolition of milk quotas in 2015 (Peyraud et al. 2014). The process of economic concentration favors livestock farms, industries, and commodities within regions with high livestock density such as Brittany, France (Peyraud et al. 2014). Except for sheep and suckler cattle systems, this phenomenon builds on a trend of intensification of animal production based on highly productive breeds, confinement systems, and off-farm feed purchase (often complete feed, guaranteeing high animal performance). Recent progress in communication technology strengthens this trend towards specialization, since it addresses workload problems by enabling long-distance monitoring of livestock buildings and intervention: automatic feeding and control of individual animal performance. These changes simplify farmers' work (De Koning and Rodenburg 2004; Schewe and Stuart 2014).

These drivers of specialization are highly consistent with the socio-economic context of production, and will be particularly difficult to unlock without significant changes in the dominant socio-technical regime (Geels 2004; Horlings and Marsden 2011). Beyond the investments required to revert to diversified and integrated crop-livestock systems (purchasing specific machinery, fencing plots to hold animals, building or renovating animal buildings, etc.), which are often impossible for individual farmers, the skills and knowledge required to manage crop-livestock systems have often been lost after specialization.

\subsection{Aims and scope of this review}

While advantages of crop-livestock integration at the farm level have been widely studied, several authors (Bos and van de Ven 1999; Lemaire et al. 2014; Moraine et al. 2014, 2016a; Peyraud et al. 2014; Russelle et al. 2007; Wilkins 2008) suggest that crop-livestock integration can be structurally organized beyond the farm level through local groups of farmers negotiating land-use allocation patterns and exchanging materials (manure, straw, etc.). For instance, in regions with high animal density, manure exchange among farms is a common example of crop-livestock integration avoiding or at least decreasing environmental impacts of livestock farms, such as nutrient runoff (by avoiding or at least decreasing excess manure applications), and promoting ecosystem services such as maintenance of soil structure and fertility on 
crop farms (Asai et al. 2014b). However, crop-livestock integration beyond the farm level remains seldom studied (Asai et al. 2014a, b; Moraine et al. 2016b; Russelle et al. 2007) and the scarce examples build on normative methods (Bos and van de Ven 1999). Thus, at the moment, research on crop-livestock integration beyond the farm level mainly deals with environmental aspects but neglects management and organizational aspects that might explain implementation problems (Moraine et al. 2014, 2016a; Noe and Hugo 2015). Development of such a collective agricultural system raises questions, rarely documented in the literature, about how to integrate crops and livestock beyond the farm level, and the consequences, impacts, and conditions of integrating them. Given this lack of knowledge on crop-livestock integration beyond the farm level, dedicated decision support systems (DSS) have never been developed. Available DSS dealing with crop-livestock integration (e.g., farm models like Martin et al. 2011; Le Gal et al. 2013) are focused on the farm level and consequently do not take into account organizational aspects among farms. Thus, these DSS are not relevant to support development of crop-livestock integration beyond the farm level based on organizational coordination among farms.

In this context, the aims of this review are:

(i) to clarify the different forms of crop-livestock integration beyond the farm level and the benefits and limits related to these different forms

(ii) to identify the required features and related research issues of DSS for developing crop-livestock integration beyond the farm level based on organizational coordination among farms

\section{Benefits and limits to crop-livestock integration beyond the farm level}

\subsection{Crop-livestock integration beyond the farm level: how?}

According to several authors (Bonaudo et al. 2013; Lemaire et al. 2014; Moraine et al. 2014), crop-livestock integration pursues three aims: reducing the openness of nutrient cycles, following the rationale of industrial ecology, organizing land use and farming practices to promote ecosystem services, and increasing farm resilience to adverse climatic and economic events. To achieve these aims, two types of integration between crops, grasslands, and animals can be managed over space (co-location vs. segregation) and time (synchronization vs. rotation) (Bell and Moore 2012). Following this categorization, Moraine et al. (2014, 2016a) classify crop-livestock systems according to temporal and/or spatial integration between crops, grasslands, and animals and their impacts on nutrient cycling and ecosystem services. We adapt the four types distinguished by these authors to characterize crop-livestock integration beyond the farm level according to spatial, temporal, and organizational coordination among farms (Table 1):

- Type 1, "global coexistence": exchange of raw materials (grain, forage, straw, etc.) among farms through national or global markets. Exchanges are driven by the global balance between supply and demand for these materials, which is determined by market size, nature of goods, prices, etc. Geographic dispersion of farms makes it difficult and costly to exchange products with low nutrient concentration, such as slurry. Type 1 is based on spatial and temporal segregation of crop and livestock productions and does not involve direct coordination among farmers. Most specialized farms in the Northern Hemisphere are currently organized according to this rationale (Horlings and Marsden 2011).

- Type 2, "local coexistence": relocation of raw materials exchanges among farms through a local economic organization such as an agricultural cooperative (e.g., Moraine et al. 2016b). Exchanges are driven by local demand for these materials, and their development may promote introduction of forage and cover crops in crop rotations in specialized crop farms to respond to the demand for forage products (Sulc and Tracy 2007). Grain and forage can be collected and possibly stored, transported, and sold to livestock farmers by the local organization. A similar form of transfer can be implemented to transfer manure from livestock farms to crop farms. However, because Type 2 does not involve direct coordination among farmers, the magnitude of exchanges will rely on intermediary activities and this local market ought to be coordinated by local economic organizations which quantitatively and qualitatively buffer variability in exchangeable raw materials over time.

- Type 3, "complementarity": direct exchange of raw materials between farms. This form of integration involves strategic planning among crop and livestock farmers to match supply and demand for feedstuff through adapted crop rotations including grasslands, forage crops, and cover crops that produce forage. It can also optimize manure allocation based on comparative advantages of field soils of participating farms (Asai et al. 2014b; Wagner et al. 2008). Type 3 involves temporal coordination of one-way flow or exchanges of raw materials between spatially segregated farms. Accordingly, it requires direct and frequent coordination between 


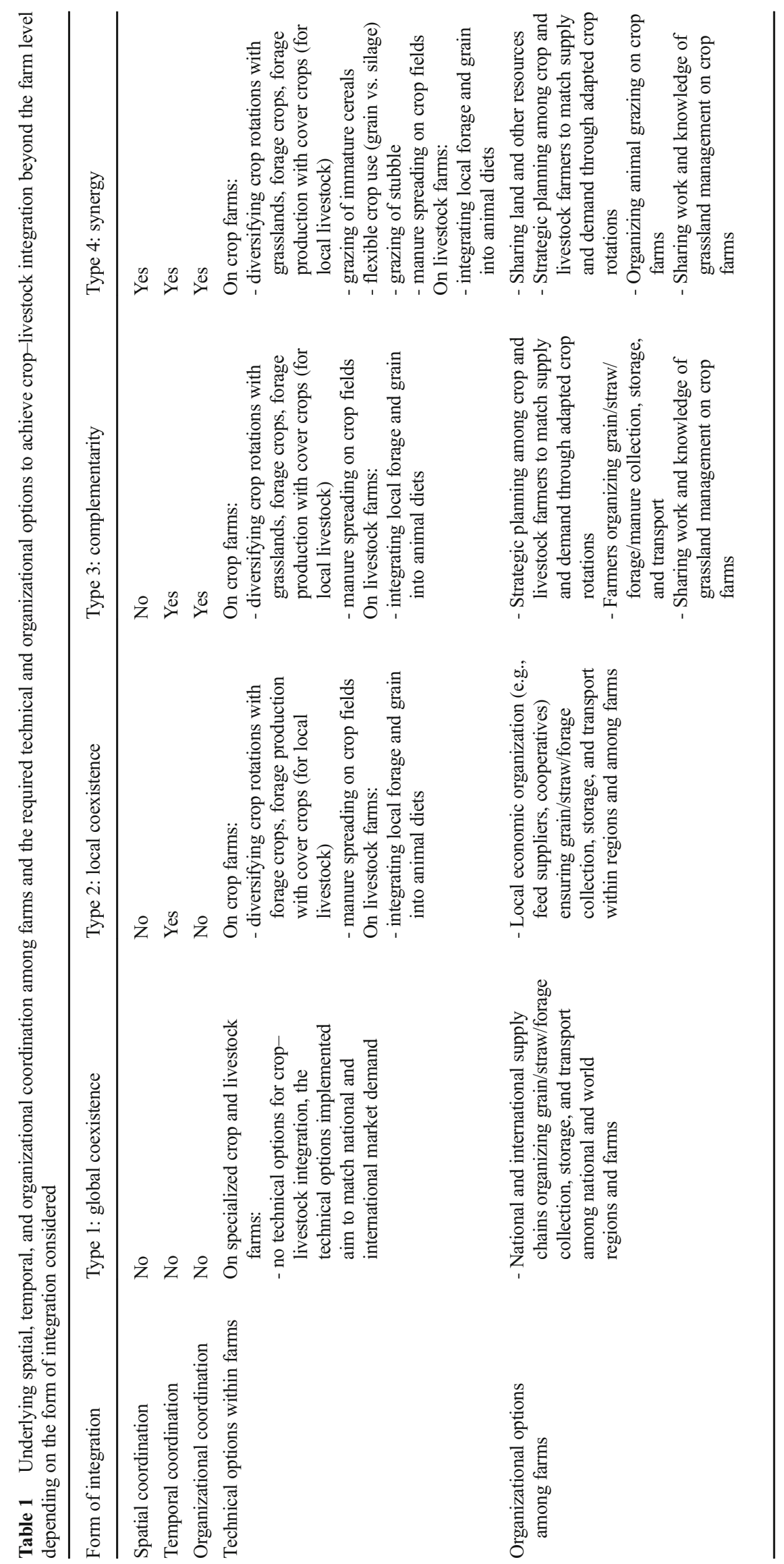


farmers for strategic planning to respond to variability in quantity and quality of exchangeable materials.

- Type 4, "synergy": strong temporal and spatial integration between crops, grasslands, and animals among farms. Overall, it involves resource sharing, mainly land sharing: farmers group their respective land areas and collectively plan land use of each field and animal movements. Thus, synergy is also based on practices such as stubble grazing; sacrificial grazing of grain crops; introducing intercropped forage crops, temporary grasslands, and forage legumes in crop rotations; grazing animals from livestock farms on crop farms (Moraine et al. 2014, 2016a); and arrangements such as potato-dairy systems (Russelle et al. 2007). Coordination between farmers must be strong and long-lasting to manage rotational manure application and occurrence of grasslands in crop rotations.

While local coexistence (type 2) presupposes existence of diversity of farms within a region or neighboring regions displaying different types of farms, the complementarity and synergy forms of integration (types 3 and 4) exclusively require existence of diversity of farms within a region due to the nature and intensity of spatiotemporal interactions.

The following sections address ecosystem services and economic and social benefits promoted by crop-livestock integration beyond the farm level. These services and benefits are not exclusive to this level of analysis. Few of them also apply to the farm level but the analysis is restricted to the beyond-farm level.

\subsection{Crop-livestock integration beyond the farm level to promote ecosystem services}

\subsubsection{Ecosystem services and agriculture}

The ecosystem services framework enables to characterize trade-offs among different types of services. Indeed, agricultural systems both provide and benefit from ecosystem services (Garbach et al. 2014; Zhang et al. 2007). Focusing on the influence of agricultural activities on ecosystem services, Le Roux et al. (2008) distinguish three types of ecosystem services: (i) input services provided to farmers, which support production and reduce use of synthetic inputs and energy; (ii) production services (or goods), which provide raw agricultural materials (plant and animal products) to society; and (iii) nonmarket services, which are provided by agricultural ecosystems to society and result from regulation of biogeochemical cycles at field and landscape levels (Garbach et al. 2014; Rusch et al. 2010).

Input services may be the key services expected by farmers implementing crop-livestock integration beyond the farm level since they benefit their farms (Moraine et al. 2016a). They correspond mainly to maintenance of soil fertility (including soil structure and nutrient cycling), erosion control, and biological regulation (including pollination) (Garbach et al. 2014). They depend on management of agricultural areas but also other areas, such as (semi-)natural habitats (Power 2010; Rusch et al. 2010). It is well recognized that they are mainly determined by management of planned and associated biodiversity at different spatial and temporal scales, from field to landscape and from sub-annual period (e.g., intercrop) to the duration of a crop rotation, respectively (Gaba et al. 2014; Garbach et al. 2014; Koohafkan et al. 2011; Power 2010; Rusch et al. 2010). Non-market ecosystem services, mainly water quality and flow regulation, carbon (C) sequestration, climate regulation (regulation of greenhouse gas (GHG) emissions), and production of natural habitats and attractive recreational areas, are also strongly determined by farming practices (Garbach et al. 2014).

Through land-use modification at the field, farm, and landscape levels, agricultural systems influence ecosystem structure and processes that in turn determine ecosystem services. Developing ecosystem services through agriculture involves working across organization levels on the causal chain: management practices-property (state)-process (intensity)-service (level) (Carpenter et al. 2011; Robinson et al. 2012). Several authors have identified that cooperation (like the complementarity and synergy forms of crop-livestock integration, types 3 and 4) is often necessary to solve problems relating to natural resources, since the geographic nature and scale of many environmental issues tend to require management across legal and administrative boundaries (Bodin and Crona 2009). The typical example is to achieve ecosystem services that require spatial consistency and for which the only farm-level management is inadequate, requiring cooperation of multiple landholders (Cong et al. 2014; Emery and Franks 2012; Stallman 2011). Currently, few agricultural systems manage ecosystem services at levels larger than fields due to lack of knowledge about monitoring of underlying ecological processes and to poor coordination between farmers.

\subsubsection{Soil fertility services promoted by crop-livestock integration beyond the farm level}

Ecosystem services are strongly influenced by the nature, size, and spatial configuration of the crop, grassland, and animal components of the farms and landscapes in which they are located. In particular, spatial location, temporal duration, and intensification level of cover crops (Gaba et al. 2014; Lemaire et al. 2014), grasslands (Soussana and Lemaire 2014), and legumes strongly influence soil fertility (Tilman et al. 2002; Tribouillois et al. 2015). Starting from cropping systems of specialized cash crop farms, crop-livestock integration beyond the farm level promotes introduction of cover crops, 
legumes, and short-duration grasslands. These changes favor recoupling of $\mathrm{C}, \mathrm{N}$, and $\mathrm{P}$ cycles.

Compiling the results of 30 studies conducted in 37 study sites all across the world, Poeplau and Don (2014) found that cover cropping increased soil carbon content by $0.32 \mathrm{Mg} \mathrm{C} \mathrm{ha}^{-1} \mathrm{yr}^{-1}$ most often during 50 years at least. In their meta-analysis of cover crop effects on $\mathrm{N}$ dynamics, Tonitto et al. (2006) showed that cover cropping increases $\mathrm{N}$ retention via $\mathrm{C}-\mathrm{N}$ recoupling and in turn strongly reduces nitrate leaching (from about $40 \%$ in legume cover crop to $70 \%$ in non-legume cover crop, see also Constantin et al. 2012 and Gardner and Drinkwater 2009). Thus, cover crops recouple C, N, and P cycles (Drinkwater and Snapp 2007). They also allow reducing runoff and erosion. For instance, in a study conducted in Mexico, Zhu et al. (1989) showed that implementation of cover crops reduced runoff by 44 to $53 \%$ depending on the species cropped. More generally, Schipanski et al. (2014) simulated that introduction of cover crops in a 3year soybean-wheat-corn rotation in a typical Mid-Atlantic climate (US) increases ecosystem services related to $\mathrm{C}$ and $\mathrm{N}$ cycles and to soil erosion without negatively influencing crop yields.

Legumes in pure stands or in mixtures link C-N-P cycles through symbiotic N fixation (Drinkwater and Snapp 2007). Symbiotic N fixation by legumes can range from 100 to $380 \mathrm{~kg} \mathrm{~N} \mathrm{ha}^{-1} \mathrm{yr}^{-1}$ according to the species of legumes and to soil-climate conditions (Lüscher et al. 2014b). Experiments in Europe and in the USA have shown that alfalfa-crop rotations provide an equivalent of $100-200 \mathrm{~kg}$ of mineral $\mathrm{N}$ for subsequent maize and cereal crops (Baldock et al. 1981; Ballesta and Lloveras 2010). Intercropping including legumes favors positive interactions between $\mathrm{N}_{2}$-fixing and non $\mathrm{N}_{2^{-}}$ fixing plants. For instance, in Southwestern France, durum wheat-winter pea intercrops resulted in land use equivalent ratios till $19 \%$ higher than that of sole crops (Bedoussac and Justes 2010). Grass-legume intercropping or mixed grasslegume swards also reduce nitrate leaching (Lüscher et al. 2014b; Drinkwater et al. 1998). Vertès et al. (1997) found a reduction by $5-10 \%$ under grass-clover compared to pure grass swards. Deep roots of some legumes improve soil structure and soil permeability facilitating water infiltration (Snapp et al. 2005; Blumenthal and Russelle 1996).

Short-duration grasslands are a third option to recouple CN-P cycles. At the field level, a range of 30-50\% of legumes seems optimal for promoting coupling of $\mathrm{C}, \mathrm{N}$, and $\mathrm{P}$ cycles and abovementioned ecosystem services provided by legumes (Lüscher et al. 2014b; Soussana and Lemaire 2014; Soussana et al. 2004). Moreover, Poeplau et al. (2015) showed that C sequestration potential of perennial ryegrass in Sweden and in the USA was $0.32 \mathrm{Mg} \mathrm{C} \mathrm{ha}^{-1} \mathrm{yr}^{-1}$. Kunrath et al. (2015) reported that nitrate leaching decreased exponentially as the proportion of grassland increased within crop rotations. Souchère et al. (2003) have simulated that substitution of
$17 \%$ of grasslands with crops in Normandy, France, led to an increase of runoff volume by $75 \%$ and of soil loss by $85 \%$.

The longer the duration of cover crops, legumes, and shortduration grasslands in a crop rotation, the greater their potential to increase soil fertility (and decrease $\mathrm{N}$ losses). Local coexistence (type 2) may already promote diversification of crop rotations with cover crops, grasslands, and forage crops that include legumes (Tables 1 and 2). With complementarity (type 3 ) and synergy (type 4), coordination between crop and livestock farmers to match supply and demand for animal feedstuff promotes an increase in cover crops, grasslands, and legumes in crop rotations (Tables 1 and 2).

Immobilizing $\mathrm{C}, \mathrm{N}$, and $\mathrm{P}$ in relatively stable and abundant organic matter forms, i.e., with a significant "mean residence time," is the key determinant of the extent and resilience of a soil's ability to autonomously provide nutrients adapted to crop requirements and decrease nutrient losses to the environment (Drinkwater and Snapp 2007; Soussana and Lemaire 2014). These processes can be strengthened by manure application (as suggested for local coexistence, complementarity and synergy - types 2, 3, and 4) through mechanical spreading or grazing, which increases the size and diversity of soil microbial populations and the biological fertility of soils (Diacono and Montemurro 2010).

According to the intensification level, grazing of grasslands, cover crops, legumes, and crop residues (as in synergy, type 4) can improve or degrade soil fertility by coupling or decoupling C, N, and P (Carvalho et al. 2010; Soussana and Lemaire 2014). For instance, Ledgard et al. (2009) reported a doubling of nitrate leaching from 30 to $60 \mathrm{~kg} \mathrm{~N} \mathrm{ha}^{-1} \mathrm{yr}^{-1}$ by increasing milk yields per hectare from 13,200 to $15,500 \mathrm{~kg}$ milk ha ${ }^{-1} \mathrm{yr}^{-1}$. The threshold above which landuse intensification is associated with a strong increase in environmental risks is highly site-dependent (Lemaire et al. 2014; Soussana and Lemaire 2014). Depending on the site, beneficial effects can be increased or decreased through reduced- or no tillage in a conservation agricultural approach (Franzluebbers 2010; Tilman et al. 2002). They also depend on adaptability of farmers' management strategies to soilclimate conditions within and between years (Hendrickson et al. 2008).

\subsubsection{Biological regulation services promoted \\ by crop-livestock integration beyond the farm level}

Functional biodiversity within field (e.g., through intercropping) and directly around field (e.g., when including flowering or herbivore repelling or attracting plants) and the level of ecological intensification of agroecosystems strongly determine biological regulation of crop pests and diseases, and pollination of entomophilous crops (Altieri 1999; Bommarco et al. 2013; Gaba et al. 2014; Letourneau et al. 2011; Tonhasca and Byrne 1994). The intensity of the mobile-agent-based 
Table 2 Summary of contribution of forms of crop-livestock integration to the provision of ecosystem services

\begin{tabular}{lllll}
\hline Type of ecosystem services & $\begin{array}{l}\text { Ecosystem service } \\
\text { considered }\end{array}$ & $\begin{array}{l}\text { Type 1: global } \\
\text { coexistence }\end{array}$ & $\begin{array}{l}\text { Type 2: local } \\
\text { coexistence }\end{array}$ & $\begin{array}{l}\text { Type 3: } \\
\text { complementarity }\end{array}$ \\
\hline Soil fertility services & Soil fertility & 0 & + & + \\
& Carbon sequestration & 0 & $0 /+$ & + \\
synergy \\
$\begin{array}{l}\text { Biological regulation } \\
\text { services }\end{array}$ & Weed control & 0 & $0 /+$ & + \\
& Pest and disease control & 0 & $0 /+$ & ++ \\
\hline
\end{tabular}

Symbols "0," “+," and “++" mean no effect, a positive effect and a very positive effect on the considered service, respectively. In type 2 , provision of ecosystem services depends on introducing forage crops and temporary grasslands in crop rotations

ecosystem services (Kremen et al. 2007) is dependent on both the heterogeneity of landscapes and the within-field biodiversity and crop management (Fahrig et al. 2011; Lüscher et al. 2014a; Rusch et al. 2010).

At the landscape level, two dimensions of landscape heterogeneity influence functional biodiversity: the compositional heterogeneity, e.g., the number and proportion of different land use types and the configurational heterogeneity, e.g., the spatial arrangement of these land use types (Fahrig et al. 2011; Lüscher et al. 2014a). Integrating crops and livestock beyond the farm level allow increasing heterogeneity of both dimensions by including grassland areas in cropping landscapes (as supported by complementarity and synergy - types 3 and 4; Table 1) and by conserving semi-natural grasslands in livestock systems (compositional heterogeneity) and integrating these areas (in time and space) within the current simplified arrangement of crops (configurational heterogeneity). A positive correlation has been shown between diversity (i.e., richness and abundance) of semi-natural habitats and natural crop pest control intensity within crop fields (Chaplin-Kramer et al. 2011). Indeed, a synthesis of 72 independent studies demonstrated that landscape heterogeneity, through its higher diversity of semi-natural habitats, increases natural crop pest control intensity and hence significantly decreases pest damage levels in crops (Véres et al. 2013). Moreover, grazed grasslands in a landscape generally increase grass refuges in pastures, which often shelter large aphid colonies and are suitable reproduction sites for aphid-feeding beneficial insects (unpublished data).

At a finer scale, a diversity of crops, semi-natural habitats, and grasslands in the direct surroundings of a field (as favored by complementarity and overall synergy - types 3 and 4) also promote species richness and abundance of natural enemies of pests (Sarthou et al. 2014). A meta-analysis of 552 studies demonstrated that crop diversification from the field to the farm level is positively correlated with specific diversity of natural enemies and negatively correlated with crop pest abundance and crop damages (Letourneau et al. 2011). For instance, introduction of alfalfa within crop rotations yields these services because alfalfa flowers provide aphid parasitoids with nectar (Landis et al. 2000) and alternative hosts
(Langer and Hance 2004). Abundance of natural enemies of pests also proved to be spatially correlated with flower diversity in field-surrounding semi-natural habitats and sown strips (Tschumi et al. 2015). A similar but temporal correlation has been found by Rusch et al. (2013): crop rotation diversity at the landscape level enhances effective biological control of pests in crop fields. Organic agriculture also favors natural enemy diversity at the field and/or farm and/or landscape levels (Crowder et al. 2010; Gosme et al. 2012; Tuck et al. 2014; Puech et al. 2015). All these correlations except the temporal one (i.e., with crop rotation diversity) have also been demonstrated for wild pollinators, mainly wild bees and hoverflies (Kennedy et al. 2013; Andersson et al. 2014. Alfalfa and overall diversification of arable crop rotations favor biological control of weeds (Meiss et al. 2010) and are particularly valuable where herbicide-resistant weeds are problematic (Doole and Pannell 2008).

Such diversified landscapes, at both large and fine spatiotemporal scales, favor beneficial arthropods of crops both during their active life cycle (Landis et al. 2000) and their overwintering (Sarthou et al. 2014 and unpublished), since they offer a higher diversity of vital ecological resources to these organisms throughout the year. Indeed, almost all beneficial insects move outside fields at different periods of the year, while half of insect pests can complete their entire life cycle inside a single field (Häni et al. 1998). Diversified landscapes also reduce pest pressure by the means of ecological processes, such as resource dilution and stimulo-deterrent diversion (i.e., attraction of pests to catch crops and repulsion from cash crops), allelopathy effects, and direct and indirect architectural/physical effects (Ratnadass et al. 2012). These diversified landscapes are prone to be favored by the development of crop-livestock integration beyond the farm level (Franzluebbers et al. 2011; Table 2) and integration of forage crops in cereal cropping systems and landscapes (as suggested for local coexistence, complementarity and synergy - types 2 , 3 , and 4; Table 1).

There is still little knowledge on the relations between landscape composition and configuration and the different requirements of natural enemies involved in biological regulations so that it is difficult to further conclude on biological regulation 
services promoted by crop-livestock integration beyond the farm level. Still, it seems that landscape-level biological regulations could be easier to develop with the synergy (type 4) form of crop-livestock integration and when concerned farmlands are spatially continuous and contiguous. Delivering biological regulation services requires detailed social agreements among farmers to implement the right combination of biotic and/or abiotic components at the right place across the landscape and at the right time (Mace et al. 2012). Many pestmanagement studies have highlighted that adapted management strategies at multiple levels are needed to greatly reduce pesticide use (Mediene et al. 2011; Rusch et al. 2012; Scherr and McNeely 2008). In such multi-level management and ecological processes, potential cascading effects can occur, leading to virtuous or vicious circles according to the scale of the process or area considered (Galloway et al. 2008). For instance, studying the effects of landscape structure on parasitism of the rape pollen beetle and related bud damages in Northern Germany, Thies and Tscharntke (1999) found that complex landscape with high percentage of semi-natural elements and high level of connectivity allowed limiting damages. But if the semi-natural area dropped below a value of $20 \%$, the level of parasitism was dropping below 32 to $36 \%$, i.e., the threshold value below which a success in classical biological control has never been found.

\subsection{Crop-livestock integration beyond the farm level to promote economic and social benefits}

\subsubsection{Economic benefits}

Crop-livestock systems at the farm level are often considered providers of key economic benefits. Economies of scope are often cited as beneficial results obtained through the combination of complementary productions (Ryschawy et al. 2012). The same processes apply beyond the farm level. With local coexistence, complementarity, and synergy (types 2, 3, and 4), livestock farmers obtain straw and grain without needing to replace grassland with cereal crops (Havet et al. 2014). It allows creating new equilibria between land and animals providing economic opportunities. Moreover, dedicating the released land to a new category of animals could enlarge the scope of farm products.

The possibility of reorganizing spatial allocation and therefore integration between crops, grasslands (complementarity, type 3), and animals (synergy, type 4) at the collective level may develop diversified internalized markets (Dalle and Didry 1998; Havet et al. 2014; Wilkins 2008) and promote risk sharing among farmers and adaptive capacity and as a result resilience of individual farms (Darnhofer et al. 2010; Table 3). One such example that applies to complementarity and synergy (types 3 and 4 ) is the possibility for crop farmers to leave their crops to livestock farmers for sacrificial crop grazing; this strategy would address decreases in yield or quality after a technical problem or meteorological event that would hinder selling this product on the conventional market. Bell et al. (2014) reported that sacrificial grazing managed at the farm level yields economic benefits in $20-40 \%$ of the years in Australia. The potential economic impacts could apply to crop farmers involved in complementarity and synergy (types 3 and 4).

Internalized markets could also reduce the risk of income variability due to conventional market fluctuations (Peyraud et al. 2014). For instance, in Southwestern France, a group of organic crop and livestock farmers involved in a complementarity type of integration (type 3 ) has established agreements upon prices of grain and forage through pluriannual contracts (Ryschawy et al. 2016a, b). These contracts include moderate price adjustments in case of significant fluctuations of the conventional market. Moreover, with complementarity and synergy (types 3 and 4), internalized markets allow consumers to easily understand production traceability, which could strengthen their trust in the quality of agricultural production and possibly provide additional economic benefits (Pecqueur 2001).

As part of complementarity and synergy (types 3 and 4), collective organization also offers the opportunity to increase resource-use efficiency (Table 3) through spatial allocation of agricultural activities according to relative advantages of activity-location combinations of farmland (Havet et al. 2014; Lemaire et al. 2014; Wilkins 2008). It would avoid or decrease cultivation of crops on unsuitable land, which leads to inefficient resource use. For example, land where crops cannot reach desired yields may be better devoted to livestock grazing, whereas highly fertile soils could be sustainably cropped under long and diversified crop rotation without animals (Bell et al. 2014). Also, producing irrigated forage in areas with high agronomic potential where water is available and accessible at low prices (pumping from rivers or shallow wells) and transferring it to livestock farms in the same local area that do not have such fields could avoid construction of expensive water reservoirs. Improved organization of land use at the collective level should increase overall productivity and economic returns (Bell et al. 2014; Franzluebbers 2007). As for environmental benefits, expected economic benefits of integrated crop-livestock systems depend on adaptability of farmers' management strategies to soil-climate conditions within and between years (Hendrickson et al. 2008) but also to characteristics of farm structures.

\subsubsection{Social benefits}

Several social benefits are provided by crop-livestock integration beyond the farm level through organizational coordination among farmers. They are mainly promoted by the complementarity (type 3) and synergy (type 4) forms of 
Table 3 Summary of contribution of forms of crop-livestock integration to the provision of economic and social benefits

\begin{tabular}{lllll}
\hline Types of benefits & Benefit considered & $\begin{array}{l}\text { Type 1: global } \\
\text { coexistence }\end{array}$ & $\begin{array}{l}\text { Type 2: local } \\
\text { coexistence }\end{array}$ & $\begin{array}{l}\text { Type 3: } \\
\text { complementarity }\end{array}$ \\
\hline Economic benefits & Risk sharing & 0 & 0 & $\begin{array}{l}\text { Type 4: } \\
\text { synergy }\end{array}$ \\
& Resilience & 0 & 0 & + \\
& Resource-use efficiency & 0 & 0 & + \\
Social benefits & Management and workflow & 0 & 0 & + \\
& Social learning/empowerment & 0 & 0 & + \\
& Social acceptance of agriculture & 0 & + & ++ \\
\end{tabular}

Symbols "0," "+," and "++" mean no effect, a positive effect and a very positive effect on the considered service, respectively

integration. These social benefits mainly concern (i) farm management and workflow, (ii) social learning and collective empowerment, and (iii) social acceptance of agricultural activities.

Long-term analysis of work organization in diversified crop-livestock farms has shown seasonal complications in management when animal production and cropping-activity workloads conflict (Dedieu and Serviere 2012). Collective organization offered by synergy (type 4) may offer opportunities to resolve or reduce these workload problems (Table 3), while sharing specific workloads during busy periods. As already shown by Andersson et al. (2005) in Sweden, possible solutions include sharing the labor force through shared employees, task delegation, or shared tasks between farmers (e.g., for making silage), as well as shared equipment to increase productivity. These authors have shown that cooperation can increase individual and collective economic efficiency.

Complementary (type 3 ) and synergistic (type 4) reorganization of land use at the collective level may make workloads on each farm more adapted to the available quantity and skills of the work force (Table 3). Hence, transferring certain forage or grain production to crop farms may facilitate workload organization on livestock farms. Importantly, the possibility of improving farm workloads will strongly promote individual acceptance and perception of work constraints, mainly in livestock systems. It can offer new opportunities, such as having weekends off and annual vacations (Ryschawy et al. 2013).

Asai (2013) surveyed 644 intensive livestock farmers in Denmark who distributed manure to other farms. Two thirds of them reported that they had established at least one additional collaborative activity (e.g., co-work on selling/marketing) with their manure partner besides the manure arrangement. Sixteen percent of all partnerships can be assimilated into the synergy (type 4) form of integration, characterized by strong social relationships, frequent communication among partners, and long partnerships (over 10 years). In one third of the partnerships, partners had worked together on other farm activities prior to the manure partnership, while another $30 \%$ of partners used this policy-driven manure partnership as an opportunity to develop other types of collaboration to respond to internal/external conditions. This development of collaborative partnerships can be seen as a means of social innovation to strengthen farmers' ability to adapt to external changes (Table 3).

In professional groups, exchange of knowledge mainly promoted by complementarity (type 3 ) and synergy (type 4) provide increasing options for individual adaptations and the ability to collectively respond to problems (Table 3 ), such as the management of grassland allocation at the landscape level to limit runoff and soil erosion (Souchère et al. 2010). Hence, describing "collective aptitudes" in local agricultural professional groups, Darré (1999) highlights "decision-making empowerment" due to social learning through knowledge and know-how exchanges and negotiation. This process is called "capacity building" (Faure and Kleene 2004; Kilpatrick et al. 2006). It is considered a positive "informational externality" of collective organization (Dalle and Didry 1998). On-farm changes and their effects on the environment and society could encourage farmers to modify values that underlie their professional activities and promote personal development (Coquil et al. 2013; Goulet and Vinck 2012; Vounouki and Rémy 2009). It could also increase trust among farmers which contributes to lubricate cooperation and reduce transaction costs (Pretty 2003). Trust saves time dedicated to monitoring other farmers.

Crop-farm diversification could promote development of attractive recreational landscapes and more acceptable farming systems (Table 3 ). This is especially the case for local coexistence, complementarity, and synergy (types 2, 3, and 4), especially when including cover crops, legumes, and grasslands that diversify landscapes matrices and decrease mudslide risks. Reorganization of land use at the collective level could also increase conformity with environmental regulations. For instance, in Denmark, implementation of the Nitrate Directive (91/676/ EEC) has introduced a number of strict rules on nitrogen management, planning, and reporting. The rules determine how much manure each farmer is allowed to spray per unit of area. Specialized livestock farms lack sufficient land area to manage the amount of manure 
produced. Accordingly, Asai et al. (2014b) have shown that these regulations have led to the establishment of collaborative partnerships between specialized organic farms for manure exchange: in 2009, $80 \%$ of all Danish organic arable farms had formal agreements with livestock farms to receive their manure, while about $70 \%$ of organic dairy farms were involved in partnerships and exported their manure. By promoting compliance with environmental regulations, croplivestock integration beyond the farm level may improve societal acceptance of livestock and crop farms.

\subsection{Potential limitations of crop-livestock integration beyond the farm level}

\subsubsection{Cognitive and behavioral limitations}

Increased coordination among farms along with complementarity and synergy (types 3 and 4) forms of crop-livestock integration gradually makes their management more complex (Table 4; Hendrickson et al. 2008; Horlings and Marsden 2011; Moraine et al. 2016a; Sulc and Tracy 2007). This increase in complexity is related to increased diversity of practices and coordinations to manage within and between the crop, grassland, and animal components and among farmers. Farmers have to articulate doing things better (innovation through better exploitation of resources) with doing things differently (innovation through exploration of new resources) which is more complex (Maletič et al. 2014). This results in an increase in knowledge and skill requirements and classic management constraints of diversified and integrated agricultural systems: (i) knowledge gaps about the functioning of ecological and agricultural systems, e.g., the interaction between the landscape mosaic, management practices, and the resulting biological regulation of pests; (ii) imperfections and limits in detecting variations in the state of the environment under the effects of ecological processes and farming practices; (iii) the difficulty, if not impossibility, of controlling all management practices within a group of farms; and (iv) the stochastic, and thus unpredictable, character of certain ecological processes (Williams 2011). These management constraints increase transaction costs of reaching farmers' individual and collective objectives (Asai et al. 2014a).
Risk aversion and awareness of risk sharing can compromise farmers' willingness to engage in crop-livestock integration among farms (Carruthers and Vanclay 2012; Hendrickson et al. 2008). Farmers might be unwilling to face the new constraints that appear, such as loss of autonomy in decisionmaking, dependence on other farmers for decision-making and action, and involvement in partnerships of varying degrees of formality, especially with the complementarity and synergy (types 3 and 4; Table 4) forms of integration (Moraine et al. 2014). Risk aversion is influenced by external factors, such as prices of inputs on the international market. For instance, crop farmers' willingness to accept manure partly depends on the fluctuating price of mineral fertilizers: they are more open to receive manure when the price of mineral fertilizers is high (Schipanski et al. 2014). This occurred in manure partnerships between organic dairy farms and organic crop farms in Denmark: since demand for organically certified manure remains high, their partnerships lasted significantly longer than those between conventional dairy farmers and conventional crop farmers (Asai and Langer 2014).

\subsubsection{Environmental limitations}

Mismatch between supply and demand of nutrients (especially $\mathrm{N}, \mathrm{P}, \mathrm{K}$ ), partly related to location-specific characteristics (e.g., soil properties), can limit the relevance of local coexistence, complementarity, and synergy (types 2, 3, and 4; Table 4; Hendrickson et al. 2008). Especially with local coexistence, manure exchanges largely remain unidirectional: manure moves from livestock farms to crop farms, but nutrients do not necessarily return to livestock farms through feedstuff (Moraine et al. 2014; Peyraud et al. 2014). Typically, crop farmers receiving manure do not adequately account for its nutrient supply (Schmitt et al. 1999). This can be explained by uncertainty surrounding manure application related to manure nutrient content or interaction with application timing (Asai et al. 2014a). Ultimately, inadequate accounting of nutrient supply can lead to source-sink imbalances among crop and livestock farms and result in soil nutrient leaching on crop farms and soil nutrient depletion on livestock farms. In addition, with complementarity and synergy (types 3 and 4), transport of raw materials among farms can reduce efficiency of
Table 4 Summary of potential limitations to the development of forms of crop-livestock integration

\begin{tabular}{lllll}
\hline Limitation considered & $\begin{array}{l}\text { Type 1: global } \\
\text { coexistence }\end{array}$ & $\begin{array}{l}\text { Type 2: local } \\
\text { coexistence }\end{array}$ & $\begin{array}{l}\text { Type 3: } \\
\text { complementarity }\end{array}$ & $\begin{array}{l}\text { Type 4: } \\
\text { synergy }\end{array}$ \\
\hline Cognitive and behavioral & 0 & - & - & - \\
Environmental & 0 & - & - & - \\
Economic & 0 & 0 & - & - \\
Social & 0 & 0 & - & - \\
\hline
\end{tabular}

Symbols “0," “-," and “-” mean potentially no limitation, a moderate limitation, and a major limitation 
delivery circuits resulting in higher energy consumption and greenhouse gas emissions.

\subsubsection{Economic limitations}

The physical costs of transporting plant products and manure (e.g., straw-manure; Wilkins 2008) involved in complementarity and synergy (types 3 and 4) also determine their economic acceptance by farmers (Table 4). The maximum distance of economically efficient transport depends strongly on topography of the road between farms and the type of animal manure as a function of its dry matter (DM) content (Asai et al. 2014a). For instance, Dagnall et al. (2000) reported that high-DM $(\sim 70 \%)$ manure can be profitably transported up to $40 \mathrm{~km}$ from animal houses, whereas low-DM $(<10 \%)$ manure can only be transported $10 \mathrm{~km}$. Taking these economic aspects into consideration, a study in the USA (Files and Smith 2001) concluded that crop-livestock integration among farms ideally should occur within a distance of $25 \mathrm{~km}$. Considering these economic aspects and environmental side-effects (e.g., GHG emissions) is essential, since few policy incentives support this kind of coordination (Nuno et al. 2014; Sulc and Tracy 2007).

\subsubsection{Social limitations}

Social aspects are the last limitation in developing complementarity and synergy (types 3 and 4; Table 4). It requires overcoming social barriers between farmers to match crop rotations and related plant products to animal feed requirements (Paillat et al. 2009 in Peyraud et al. 2014). Difficulty in doing so has been widely observed in studies of other collaborative activities between farmers. For instance, Ingram and Kirwan (2011) investigated joint farm ventures in the UK and found that formal long-term joint ventures are challenging due to differing motivations, expectations, and concerns about farmers' respective roles in the working relationship and the validity of the legal framework. Only when an informal relationship had already been established was there a commitment to formalize a joint venture agreement. This tendency was also observed in farmers' collaboration in environmental management (Macfarlane 1998; Mills et al. 2011) and machinery sharing (Emery and Franks 2012). Ease of contact, respect, and trust are essential for the success of cross-farm cooperation in landscape-level resource management (Asai et al. 2014a; Files and Smith 2001). This could be further enhanced if farmers perceive themselves as a group acting or responding jointly with respect to a joint problem or resource (Mills et al. 2011). Here, mutual agreement implies addressing multiple and possibly diverging goals among individuals (Nuno et al. 2014) to reach consensus. A key concern for crop-livestock integration is how to deal with intra- and inter-annual variations in weather that could compromise the amounts of plant products exchanged. Long-lasting coordination between farmers requires that they work together with variation rather than against it (Lyon et al. 2011) within the framework of contracts (oral or written).

\section{Supporting the development of crop-livestock integration beyond the farm level}

\subsection{Motivations for using DSS to stimulate social learning and collective thinking}

Development of crop-livestock integration beyond the farm level is a multi-level process made of technical and organizational aspects. It requires individual and social learning, collective thinking, and negotiation within a network of stakeholders (Leeuwis 1999; Röling 2002). Interdependent stakeholders should evolve in a synergistic manner to arrive at a coordinated action. To develop sustainable situations, individual learning is not sufficient. Farmers should go through this process quite simultaneously in order to develop complementary or shared vision and understanding of the issue. Social learning and collective thinking should bring actors to enhance the quality of the output of their cooperation and the complementarity of their action. Stakeholders interactively learn about other stakeholders' perspectives, values, theories, and aspirations, and, in comparison with these, also about their own (van Mierlo et al. 2010).

DSS have been reported to promote social learning and collective thinking among farmers in a diversity of contexts (Martin 2015; Thorburn et al. 2011). DSS can be successful with regard to learning and thinking by facilitating the process of separating fact from opinion in participants' minds, by allowing discussion based on sound arguments, and by bringing new viewpoints into a sometimes polarized debate (Etienne 2003). DSS are said to enhance understanding of agricultural systems by increasing the awareness of systems' behavior through illustrating the role and the transparency of its components (Groot and Rossing 2011). DSS are useful tools to support social learning, collective thinking, and collective action that are key to the development of crop-livestock integration beyond the farm level.

\subsection{Required features of DSS for supporting the development of crop-livestock integration beyond the farm level}

\subsubsection{DSS requirements to support complementarity and synergy forms of crop-livestock integration}

Changes associated with implementation of a local coexistence (type 2) form of crop-livestock integration do not involve spatial or organizational coordination among farms. Changes concern widely encountered agricultural practices, such as diversification 
of crop rotations with forage crops, forage production with cover crops (for local livestock), manure spreading on crop fields, and integration of local grain into animal diets (Table 1). They can easily be addressed with available DSS, such as crop models (Rodriguez et al. 2014), animal nutrition models (INRA 2007), farm models (Martin et al. 2013), and logistics models at the level of local economic organization such as agricultural cooperatives (Le Gal et al. 2009). Therefore, no specific DSS needs to be developed for local coexistence.

In contrast, complementarity and synergy (types 3 and 4) require building seldom-encountered forms of spatial and overall organizational coordination among farms and farmers that cannot be addressed with available DSS. This section deals with DSS oriented towards development of these two promising (as shown in section 2) forms of integration. Complementarity involves individual farm management in the framework of collectively established organizational coordination among farms and farmers. Synergy differs from complementarity in that it is based on collective farm management, individual resources being pooled together.

DSS should be flexible enough to address both forms of integration. Farmer groups willing to implement crop-livestock integration beyond the farm level tend to design and evaluate different scenarios with increasing levels of temporal, spatial, and organizational interactions from complementarity to synergy (Ryschawy et al. 2016a, b). DSS should stimulate social learning, collective thinking, and negotiation towards collective action. This process can best be supported with temporal, spatial, and organizational simulation of crop-livestock integration. In particular, simulation should be able to represent organizational innovations and to address trade-offs between individual and collective performances by providing assessments at the farm and beyond-farm levels (Moraine et al. 2016c; Ryschawy et al. 2016a, b).

The effectiveness of scientific information and intervention in influencing societal learning and action, such as coordination between farmers in crop-livestock integration beyond the farm level, depends on three main features: credibility, salience, and legitimacy (Cash et al. 2003). "Credibility involves the scientific adequacy of the technical evidence and arguments. Salience deals with the relevance of the assessment to the needs of decision makers. Legitimacy reflects the perception that the production of information and technology has been respectful of stakeholders' divergent values and beliefs, unbiased in its conduct, and fair in its treatment of opposing views and interests" (Cash et al. 2003).

\subsubsection{DSS function, behavior, and structure}

To ensure credibility, salience, and legitimacy, DSS fostering crop-livestock integration beyond the farm level must display features that can best be described by three aspects (Gero and Kannengiesser 2008): (i) function, i.e., what the DSS is for, e.g., design and evaluation of a possible solution; (ii) behavior, i.e., how the DSS does it, e.g., simulation-based assessment of solutions designed by users; and (iii) structure, i.e., what the DSS consists of, e.g., a board game supplemented by a dynamic farm model operating at the landscape level (i.e., a group of farms).

Functions of the DSS are defined according to stakeholders' needs to achieve salience. Participatory design (i.e., involving stakeholders like farmers in one to several steps of the design process) of agricultural systems has to support the three key steps of the design process (Martin et al. 2013): (i) problem specification (current system functioning and associated multidomain issues); (ii) design of new systems, including necessary spatial, temporal, and organizational coordination among farms and farmers; and (iii) assessment across space and time of their potential effects and trade-offs between the individual and collective levels (Jakku and Thorburn 2010; Klerkx et al. 2012). It is also expected that during the design process, the DSS will structure the negotiation process between farmers (Barreteau 2003; Etienne 2003) to identify consensual solutions at the individual and collective levels and achieve legitimacy.

To achieve this aim, the behavior and structure of the DSS should rely on the conceptual framework that supports adaptation of agricultural systems proposed by Martin (2015), which has already been applied to several agricultural DSS (Berthet et al. 2015; Farrié et al. 2015; Martin et al. 2011). This framework (Fig. 2) builds on collective workshops involving researchers, agricultural consultants, and farmers who collectively manipulate boundary objects (e.g., cards and computer models). This enables simulation modeling of agricultural systems and design of adaptations such as crop-livestock integration beyond the farm level (Duru et al. 2012). Following Martin (2015), manipulated objects are of two types: (i) material objects (e.g., cards) enabling modeling, i.e., representation of the current situation and design of possible solutions to the problem, and (ii) computer objects (e.g., computer models) enabling simulation, i.e., assessment of these solutions. Material objects represent physical and

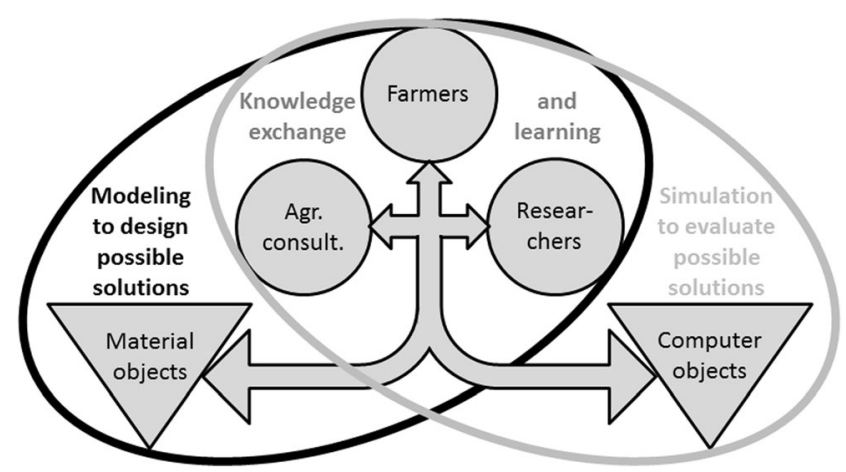

Fig. 2 Overview of the collective workshops underlying the conceptual framework of Martin (2015). Circles refer to people and triangles to boundary objects. Arrows represent interactions between people and between people and boundary objects. Bold text connected to the ovals refers to processes involving people and boundary objects 
functional entities managed by farmers, such as crops, fields, and animal groups. They are intended to create a connection between workshop participants (Klerkx et al. 2012). Computer objects (Fig. 2) provide instantaneous integrated evaluation (in the form of graphs and indicators) of candidate solutions designed by workshop participants to stimulate their reflections and negotiations. Such collective workshops are also expected to foster hybridization of scientific (to ensure credibility) and empirical knowledge (to ensure salience and legitimacy).

\subsubsection{Specific requirements of computer models}

The computer object is of key importance in the DSS. To support the three design phases, we consider a spatially explicit dynamic simulation model operating at the farm level and incorporating (i) biophysical models simulating activitylocation combinations (i.e., cropping and grassland systems under different soil and climate conditions) and herd management (e.g., animal reproduction, feeding, and production); (ii) decision models representing farmers' crop and grassland management and coordination between farmers; and (iii) logistics models representing raw material fluxes between farms and associated resource use (e.g., workforce, machinery). Simulation models developed by agricultural research are unable to cope with all characteristics of a given farming context (Ewert et al. 2002). One solution to this problem is participatory modeling and simulation that incorporates farmers' empirical knowledge into the simulation models to improve their local relevance and therefore their salience and credibility.

This computer object should allow simulation of impacts of intra- and inter-annual weather variations in crop, forage, and animal production and resulting exchanges between farms, as well as variability in individual and collective performances. Spatially explicit graphs and indicators calculated by the DSS are expected to quantify provision of ecosystem services by the simulated farms and enable identification of acceptable tradeoffs between individual and collective performances under constraints such as land suitability, labor availability, etc. (Paracchini et al. 2011; van Ittersum et al. 2008). They also encourage social learning, thereby promoting salience of the DSS (Jordan et al. 2011).

\subsection{Related issues: a matter of upscaling}

\subsubsection{Upscaling processes involved}

Developing a DSS to intensify crop-livestock integration beyond the farm level requires addressing several kinds of interrelated scale changes (Fig. 3):

- Functional (or organizational) upscaling (Ewert et al. 2011) when moving across organizational levels:

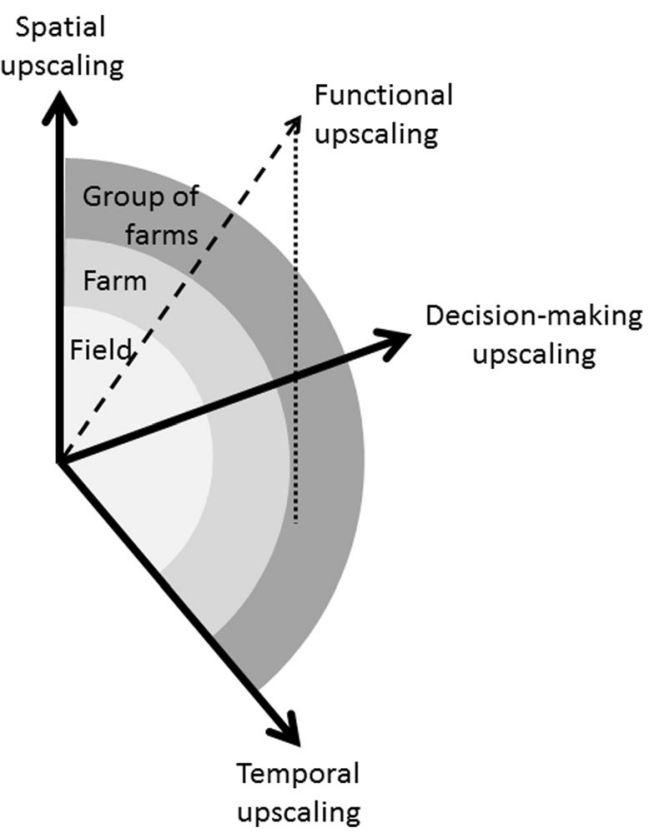

Fig. 3 Diagram of spatial, temporal, decision-making, and functional upscaling. The dotted line figures the position of the functional upscaling arrow in the three-dimensional space

from individual fields and field groups (managed similarly) to individual farms and groups of farms

- Spatial upscaling (Ewert et al. 2011) from cropping system areas to farmlands and groups of farm areas

- Temporal upscaling (Ewert et al. 2011) between the differing time steps of management and assessment periods (e.g., annual and inter-annual)

- Upscaling from individual decision-making to collective decision-making (Menter et al. 2004)

Scaling methods refer to the methods used to integrate data and models at different levels and scales. In multi-level assessment and modeling approaches, models developed at one level (e.g., plant) can theoretically provide information to models of an upper level (e.g., canopy, field). In practice, knowledge and data are not directly transportable across levels (Ewert et al. 2011). Therefore, upscaling requires defining the most salient levels of analysis to integrate across levels in the early stages of a project (Volk and Ewert 2011). This is why spatial upscaling, temporal upscaling, and upscaling from individual decisionmaking to collective decision-making all involve functional upscaling. In addition to upscaling, development of such a DSS requires anticipating its outscaling (Hermans et al. 2013), i.e., the horizontal process that consists of transposing it from one group of farmers to another, and therefore from one agricultural area to another.

\subsubsection{Outscaling}

Outscaling question the modeling approach implemented during the development of the DSS and its validity domain. It is 
essential to represent the key interactions between the subsystems (e.g., crops, grasslands, animals, and the farmer) of each level while keeping the model as simple as possible to promote transparency and as robust as possible to promote its outscaling. Previous studies have shown that scientifically credible results are not necessarily obtained with models with the highest level of detail of either biophysical (Adam et al. 2011) or decision-making processes (Martin et al. 2012). Tools and models have to be transposable among agricultural situations despite the latter's site-dependent characteristics (e.g., soil-climate conditions, crop management practices). The required DSS must combine complex systems modeling (Pahl-Wostl and Hare 2004) and low data modeling (Therond et al. 2011) to facilitate (i) calibration, especially spatialization of crop and grassland models in a landscape (Faivre et al. 2004); (ii) validation, to achieve scientific credibility and outscaling; and (iii) interaction with stakeholders to achieve salience.

\subsubsection{Spatial upscaling}

Regarding spatial upscaling, farms can be located on continuous landscapes. To promote ecosystem services through adapted land-use plans while achieving credibility and salience, a fine spatial resolution is necessary to consistently assess the fine components of the landscape matrix that determine ecosystem services (e.g., land-cover pattern, type, and spatial distribution of semi-natural habitats). Investigating large landscapes enables analysis of farmlands' neighboring effects and identifies hotspots of ecosystem services. The challenge remains to develop, collect, organize, and integrate the highresolution geographic data to combine with indicators of ecosystem services (Eigenbrod et al. 2010; Maes et al. 2012).

To achieve salience, spatial upscaling requires addressing labor requirements and costs of implementing coordination between farms. As explained previously, transportation impacts may decrease the environmental benefits of exchanges. Two characteristics of exchangeable products can be used to set a maximum transfer distance based on economic cost and environmental impacts: protein or energy density and DM content. The greater the transfer distance, the denser products must be in energy, protein, or DM to make the transfer sustainable. Therefore, the logistics involved in crop-livestock integration beyond the farm level must be modeled and simulated (Le Gal et al. 2009), for instance using energy accounting (Vigne et al. 2013) that converts energy, biophysical, and human resources involved in a given process into equivalents of a single form of energy, usually solar.

\subsubsection{Temporal upscaling}

Challenges when developing crop-livestock integration beyond the farm level include ensuring intra- and inter-annual complementarities and balancing direct and indirect (manure) crop and livestock production. It requires addressing dynamics of different types of production and constraints in their use (e.g., manure spreading) over time and across organizational levels, i.e., amounting to functional and temporal upscaling. To achieve both credibility and salience at the field level, DSS must have an adequate (intra-annual) temporal resolution, e.g., to represent ruptures in dynamics of grassland production (Martin et al. 2012) and "previous-crop" and cumulative effects of crop sequences. "Previous-crop" effects include changes in physical, chemical, and biological soil states caused by the previous crop that influence the next crop. Cumulative effects include accumulation time of effects of crop sequences on "slow variables" (Biggs et al. 2012). Tools must also deal with relations between crop sequences and annual crop plans. Diversity in crop rotation duration and farmland constraints may promote variability in annual plant production, even though relative stability is often expected.

\subsubsection{Upscaling from individual to collective decision-making}

Upscaling from individual to collective decision-making require structured methods for participatory modeling with stakeholders. Due to complexity of the problems investigated, which are usually ill-defined, it is necessary to develop a structured design process that combines hard and soft methods. This combination is intended to integrate scientific and farmers' knowledge and move from problem specification to problem solving in iterative cycles of design and assessment. Few examples (Etienne 2003) exist of structured conceptual frameworks and methods for participatory modeling with stakeholders. One key challenge is to structure the design process so that it promotes social learning and collective action (Armitage et al. 2008; Newig et al. 2008; Pahl-Wostl and Hare 2004).

Upscaling from individual to collective decision-making also involves dealing with governance and equity issues within farmer groups. These issues have long constituted the core criticism of participatory approaches. Only recently have researchers suggested methods to deal with such issues, e.g., companion modeling relying on agent-based models and role-playing games (Barnaud and van Paassen 2013; Leeuwis 2000). To date, implementation of these methods is limited to a few case studies conducted by these authors. The challenge remains to develop a consistent modeling tool that explicitly represents trade-offs and synergies between the individual and collective levels and allows transparent discussion and negotiation among farmers to find legitimate solutions to their problems.

Greater integration of crops and livestock based on managing material flows and agrobiodiversity may lead to mediation between targeted objectives and services. Various studies on ecosystem services bundles highlighted positive associations 
between environmental and cultural services. However, these two categories of ecosystem service were negatively correlated with food provisioning, e.g., economic services (Bennett et al. 2009; Raudsepp-Hearne et al. 2010; Rodríguez-Ortega et al. 2014; Ryschawy et al. 2016b). Therefore, development of crop-livestock integration should strengthen the provision of different categories of ecosystem services (e.g., biological regulation, soil quality, ...) while maintaining a level of socioeconomic benefits that ensures the feasibility and acceptability of agricultural practices and the management of necessary resources (e.g., soil, material). Accordingly, DSS should allow farmers to rank the importance of the ecosystem service categories and socio-economic benefits they expect. To favor collective thinking and negotiation, and help farmers identify acceptable trade-offs between ecosystem services and socioeconomic benefits and between the individual and collective levels, DSS should provide multicriteria assessments of economic, environmental, and social performances at the individual farm and collective levels and over time. This kind of output should help farmers to assess benefits and limits of scenarios of crop-livestock integration prior to collective action.

\section{Conclusion}

We reviewed the scientific literature to identify the potential for restoring the sustainability of agricultural systems by developing crop-livestock integration beyond the farm level through coordination among specialized farms. Three forms of integration, i.e., local coexistence, complementarity, and synergy, can be implemented that correspond to a gradient of spatial, temporal, and organizational coordination among farms and farmers. Each of these three forms promote successively higher provision of soil fertility and biological regulation services through increased temporal and spatial integration between the crop, grassland, and animal components of specialized farms. Economic and especially social benefits are expected to increase along with these forms of integration beyond the farm level. Limitations related to increased complexity of farm management and to aversion to risks of collective organization can be addressed by developing adapted DSS. By enabling farmers to design and assess potential solutions to spatial, temporal, and organizational coordination, DSS that include spatially explicit simulation of crop-livestock integration options beyond the farm level may reduce uncertainty about its implementation and stimulate social learning among farmers. When implementing these DSS with farmers, attention should be paid to consequences on governance and equity issues within farmer groups. Coordination should not strengthen the power of some farmers at the expense of others. Research in the field of economics and political science is now needed to identify policy incentives dedicated to facilitate implementation of crop-livestock integration beyond the farm level.

Acknowledgments This work was funded by the INRA EA division and by the French ANR Agrobiosphère program as part of the TATABOX project (ANR-13-AGRO-0006). It has benefited from discussions that occurred in the CANTOGETHER project (Crops and ANimals TOGETHER, FP7, Grant agreement No. 289328), funded by the European Commission's Seventh Framework Program (Food, Agriculture and Fisheries, Biotechnology).

\section{References}

Adam M, Van Bussel LGJ, Leffelaar PA, Van Keulen H, Ewert F (2011) Effects of modelling detail on simulated potential crop yields under a wide range of climatic conditions. Ecol Model 222:131-143. doi:10.1016/j.ecolmodel.2010.09.001

Altieri MA (1999) The ecological role of biodiversity in agroecosystems. Agric Ecosyst Environ 74:19-31. doi:10.1016/S0167-8809(99 )00028-6

Andersson GKS, Ekroos J, Stjernman M, Rundlöf M, Smith HG (2014) Effects of farming intensity, crop rotation and landscape heterogeneity on field bean pollination. Agric Ecosyst Environ 184:145-148. doi:10.1016/j.agee.2013.12.002

Andersson H, Larsen K, Lagerkvist CJ, Andersson C, Blad F et al (2005) Farm cooperation to improve sustainability. Ambio 34:383-387, http://www.jstor.org/stable/4315619

Armitage D, Marschke M, Plummer R (2008) Adaptive co-management and the paradox of learning. Glob Environ Chang 18:86-98. doi:10.1016/j.gloenvcha.2007.07.00

Asai M (2013) Understanding collaborative partnerships between farmers: the case of manure partnerships. PhD Thesis, Department of Plant and Environmental Sciences, University of Copenhagen, Copenhagen, Denmark, p. 119

Asai M, Langer V, Frederiksen P, Jacobsen BH (2014a) Livestock farmer perceptions of successful collaborative arrangements for manure exchange: a study in Denmark. Agric Syst 128:55-65. doi:10.1016/j.agsy.2014.03.007

Asai M, Langer V, Frederiksen P (2014b) Responding to environmental regulations through collaborative arrangements: social aspects of manure partnerships in Denmark. Livest Sci 167:370-380. doi:10.1016/j.livsci.2014.07.002

Asai M, Langer V (2014) Collaborative partnerships between organic farmers in livestock-intensive areas of Denmark. Org Agric 4:6377. doi:10.1007/s13165-014-0065-3

Baldock JO, Higgs RL, Paulson WH, Jackobs JA, Shrader WD (1981) Legume and mineral $\mathrm{N}$-effects on crop yields in several crop sequences in the upper Mississippi valley. Agron J 73:885-890. doi:10.2134/agronj1981.00021962007300050031x

Ballesta A, Lloveras J (2010) Nitrogen replacement value of alfalfa to corn and wheat under irrigated Mediterranean conditions. Span J Agric Res 8:159-169. doi:10.5424/sjar/2010081-1155

Barnaud C, van Paassen A (2013) Equity, power games, and legitimacy: dilemmas of participatory natural resource management. Ecol Soc 18:21. doi:10.5751/ES-05459-180221

Barreteau O (2003) The joint use of role-playing games and models regarding negotiation processes: characterization of associations. $\mathrm{J}$ Artif Society Soc Simul 6(2). http://jasss.soc.surrey.ac.uk/6/2/3.html

Bedoussac L, Justes E (2010) The efficiency of a durum wheat-winter pea intercrop to improve yield and wheat grain protein concentration depends on N availability during early growth. Plant Soil 330:1935. doi:10.1007/s11104-009-0082-2 
Bell LW, Moore AD (2012) Integrated crop-livestock systems in Australian agriculture: trends, drivers and implications. Agric Syst 111:1-12. doi:10.1016/j.agsy.2012.04.003

Bell LW, Moore AD, Kirkegaard JA (2014) Evolution in crop-livestock integration systems that improve farm productivity and environmental performance in Australia. Eur J Agron 57:10-20. doi:10.1016/j. eja.2013.04.007

Bennett EM, Peterson GD, Gordon LJ (2009) Understanding relationships among multiple ecosystem services. Ecol Lett 12:13941404. doi:10.1111/j.1461-0248.2009.01387.x

Berthet E, Barnaud C, Girard N, Labatut J, Martin G (2015) How to foster agro-ecological innovations? A comparison of participatory design methods. J Environ Plan Manag. doi:10.1080 /09640568.2015.1009627, in press

Billen G, Beusen A, Bouwman L, Garnier J (2010) Anthropogenic nitrogen autotrophy and heterotrophy of the world's watersheds: past, present, and future trends. Glob Biogeochem Cycles 24:GB0A11. doi:10.1029/2009GB003702

Biggs R, Schlüter M, Biggs D, Bohensky EL, BurnSilver S et al (2012) Toward principles for enhancing the resilience of ecosystem services. Annu Rev Environ Resour 37:421-448. doi:10.1146 /annurev-environ-051211-123836

Blumenthal JM, Russelle MP (1996) Subsoil nitrate uptake and symbiotic dinitrogen fixation by alfalfa. Agron J 88:909-915. doi:10.2134 /agronj1996.00021962003600060010x

Bodin Ö, Crona BI (2009) The role of social networks in natural resource governance: what relational patterns make a difference? Glob Environ Chang 19:366-374. doi:10.1016/j.gloenvcha.2009.05.002

Bonaudo T, Bendahan AB, Sabatier R, Ryschawy J, Bellon S et al (2013) Agroecological principles for the redesign of integrated croplivestock systems. Eur J Agron 57:43-51. doi:10.1016/j. eja.2013.09.010

Bommarco R, Kleijn D, Potts SG (2013) Ecological intensification: harnessing ecosystem services for food security. Trends Ecol Evol 28:230-238. doi:10.1016/j.tree.2012.10.012

Bos JFFP, Van De Ven GWJ (1999) Mixing specialized farming systems in Flevoland (The Netherlands): agronomic, environmental and socio-economic effects. NJAS Wagening J Life Sci 47:185-200

Carpenter SR, Cole JJ, Pace ML, Batt R et al (2011) Early warnings of regime shifts: a whole-ecosystem experiment. Science 332:10791082. doi: $10.1126 /$ science. 1203672

Carruthers G, Vanclay F (2012) The intrinsic features of environmental management systems that facilitate adoption and encourage innovation in primary industries. J Environ Manag 110:125-134. doi:10.1016/j.jenvman.2012.06.003

Carvalho PCF, Anghinoni I, Moraes A (2010) Managing grazing animals to achieve nutrient cycling and soil improvement in no-till integrated systems. Nutr Cycl Agroecosyst 88:259-273. doi:10.1007/s10705010-9360-x

Cash DW, Clark WC, Alcock F, Dickson NM, Eckley N et al (2003) Knowledge systems for sustainable development. Proc Natl Acad Sci U S A 100:8086-8091. doi:10.1073/pnas.1231332100

Chaplin-Kramer R, O’Rourke ME, Blitzer EJ, Kremen C (2011) A metaanalysis of crop pest and natural enemy response to landscape complexity. Ecol Lett 14:922-932. doi:10.1111/j.14610248.2011.01642.x

Cong RG, Smith HG, Olsson O, Brady M (2014) Managing ecosystem services for agriculture: will landscape-scale management pay? Ecol Econ 99:53-62. doi:10.1016/j.ecolecon.2014.01.007

Constantin J, Beaudoin N, Launay M, Duval J, Mary B (2012) Long-term nitrogen dynamics in various catch crop scenarios: test and simulations with STICS model in a temperate climate. Agric Ecosyst Environ 147:36-46. doi:10.1016/j.agee.2011.06.006

Coquil X, Béguin P, Dedieu B (2013) Transition to self-sufficient mixed crop-dairy farming systems. Renew Agric Food Syst 29:195-215. doi:10.1017/S1742170513000458
Crowder DW, Northfield TD, Strand MR, Snyder WE (2010) Organic agriculture promotes evenness and natural pest control. Nature 466: 109-112. doi:10.1038/nature09183

Dagnall S, Hill J, Pegg D (2000) Resource mapping and analysis of farm livestock manures - assessing the opportunities for biomass-toenergy schemes. Bioresour Technol 71:225-234. doi:10.1016 /S0960-8524(99)00076-0

Dalle JM, Didry C (1998) Les approximations de la proximité comme catégorie de l'action publique. In: Bellet M, Kirat T, Largeron C (eds) Approches multiformes de la proximité. Hermès, Paris, pp 309-325 (in French)

Darnhofer I, Bellon S, Dedieu B, Milestad R (2010) Adaptiveness to enhance the sustainability of farming systems. A review. Agron Sustain Dev 30:545-555. doi:10.1051/agro/2009053

Darré JP (1999) La production de connaissances pour l'action. INRA (Eds.), Paris, 244 p. (in French)

De Koning K, Rodenburg J (2004) Automatic milking: state of the art in Europe and North America. In: Meijerling A, Hogeveen H, De Koning CJM (eds) A better understanding of automatic milking. Wageningen Academic Publishers, Wageningen, pp 27-37

Dedieu B, Serviere G (2012) Vingt ans de recherche - développement sur le travail en élevage: acquis et perspectives. INRA Prod Anim 25: 85-100, http://www6.inra.fr/productions-animales/2012-Volume25/Numero-2-2012/Vingt-ans-de-recherche-developpement

Diacono M, Montemurro F (2010) Long-term effects of organic amendments on soil fertility. A review. Agron Sustain Dev 30:401-422. doi:10.1051/agro/2009040

Doole JG, Pannell DJ (2008) Role and value of including lucerne (Medicago sativa L.) phases in crop rotations for the management of herbicide-resistant Lolium rigidum in Western Australia. Crop Prot 27:497-504. doi:10.1016/j.cropro.2007.07.018

Doole JG, Pannell DJ, Revell CK (2009) Economic contribution of French serradella (Ornithopus sativus Brot.) pasture to integrated weed management in Western Australian mixed-farming systems: an application of compressed annealing. Aust J Agric Resour Econ 53:193-202. doi:10.1111/j.1467-8489.2007.00448.x

Drinkwater LE, Snapp SS (2007) Nutrients in agriculture: rethinking the management paradigm. Adv Agron 92:163-186. doi:10.1016 /S0065-2113(04)92003-2

Drinkwater LE, Wagoner P, Sarrantonio M (1998) Legume-based cropping systems have reduced carbon and nitrogen losses. Nature 396:262-265. doi:10.1038/24376

Duru M, Felten B, Theau JP, Martin G (2012) A modelling and participatory approach for enhancing learning about adaptation of grassland-based livestock systems to climate change. Reg Environ Chang 12:739-750. doi:10.1007/s10113-012-0288-3

Duru M, Therond O, Martin G, Martin-Clouaire R, Magne MA et al (2015) How to implement biodiversity-based agriculture to enhance ecosystem services: a review. Agron Sustain Dev. doi:10.1007 /s13593-015-0306-1, in press

Eigenbrod F, Armsworth PR, Anderson BJ, Heinemeyer A, Gillings S et al (2010) The impact of proxy-based methods on mapping the distribution of ecosystem services. J Appl Ecol 47:377-385. doi:10.1111/j.1365-2664.2010.01777.x

Emery SB, Franks JR (2012) The potential for collaborative agrienvironment schemes in England: can a well-designed collaborative approach address farmers' concerns with current schemes? J Rural Stud 28:218-231. doi:10.1016/j.jrurstud.2012.02.004

Etienne M (2003) SYLVOPAST: a multiple target role-playing game to assess negotiation processes in sylvopastoral management planning. J Artif Soc Soc Simul 6:2, http://jasss.soc.surrey.ac.uk/6/2/5.html

Ewert F, Rodriguez D, Jamieson PD, Semenov MA, Mitchell RAC et al (2002) Effects of elevated CO2 and drought on wheat: testing crop simulation models for different experimental and climatic conditions. Agric Ecosyst Environ 93:249-266. doi:10.1016/S01678809(01)00352-8 
Ewert F, Van Ittersum MK, Heckelei T, Therond O, Bezlepkina I et al (2011) Scale changes and model linking methods for integrated assessment of agri-environmental systems. Agric Ecosyst Environ 142:6-17. doi:10.1016/j.agee.2011.05.016

Fahrig L, Baudry J, Brotons L, Burel FG, Crist TO et al (2011) Functional landscape heterogeneity and animal biodiversity in agricultural landscapes. Ecol Lett 14:101-112. doi:10.1111/j.1461-0248.2010.01559.x

Faivre R, Leenhardt D, Voltz M, Benoit M, Papy F et al (2004) Spatialising crop models. Agronomy 24:205-217. doi:10.1007 /978-90-481-2666-8 42

Farrié B, Jouven M, Launay F, Moreau JC, Moulin CH et al (2015) Rangeland Rummy to support adaptive management of rangelandbased livestock systems. J Environ Manag 147:236-245. doi:10.1016/j.jenvman.2014.08.018

Faure G, Kleene P (2004) Lessons from new experiences in extension in West Africa: management advice for family farms and farmers' governance. J Agric Educ Ext 10:37-49. doi:10.1080 $/ 13892240485300061$

Files AC, Smith SN (2001) Agricultural integration: systems in action. Maine Agric. Center Publ. 002. Available at:http://fr.slideshare. net/Aliki85w/agricultural-integration-systems-in-action-theuniversity-of-maine

Franzluebbers AJ (2007) Integrated crop-livestock systems in the southeastern USA. Agron J 99:361-372. doi:10.2134/agronj2006.0076

Franzluebbers AJ (2010) Achieving soil organic carbon sequestration with conservation agricultural systems in the southeastern United States. Soil Sci Soc Am J 74:347-357. doi:10.2136/sssaj2009.0079

Franzluebbers AJ, Sulc RM, Russelle MP (2011) Opportunities and challenge for integrating North-American crop and livestock systems. In: Lemaire G, Hodgson J, Chabbi A (eds) Grassland productivity and ecosystem services. CAB Int, Wallingford, pp 208-218

Gaba S, Lescourret F, Boudsocq S, Enjalbert J et al (2014) Multiple cropping systems as drivers for providing multiple ecosystem services: from concepts to design. Agron Sustain Dev 35:607-623. doi:10.1007/s13593-014-0272-z

Galloway JN, Trends R, Townsend AR, Erisman JW, Bekunda M et al (2008) Transformation of the nitrogen cycle: potential solutions. Science 320:889-892. doi:10.1126/science.1136674

Garbach K, Milder JC, Montenegro M, Karp DS, DeClerke F (2014) Biodiversity and Ecosystem Services in Agroecosystems. Encycl Agric Food Syst 2. DOI:10.1016/B978-0-444-52512-3.00013-9

Gardner JB, Drinkwater LE (2009) The fate of nitrogen in grain cropping systems: a meta-analysis of $15 \mathrm{~N}$ field experiments. Ecol Appl 19: 2167-2184. doi:10.1890/08-1122.1

Geels FW (2004) From sectoral systems of innovation to socio-technical systems. Insights about dynamics and change from sociology and institutional theory. Res Policy 33:897-920. doi:10.1016/j. respol.2004.01.015

Gero JS, Kannengiesser U (2008) An ontological account of Donald Schön's reflection in designing. Int J Des Sci Technol 15:77-90

Groot JCJ, Rossing WAH (2011) Model-aided learning for adaptive management of natural resources: an evolutionary design perspective. Methods Ecol Evol 2:643-650. doi:10.1111/j.2041-210 X.2011.00114.x

Gosme M, de Villemandy M, Bazot M, Jeuffroy MH (2012) Local and neighbourhood effects of organic and conventional wheat management on aphids, weeds, and foliar diseases. Agric Ecosyst Environ 161:121-129. doi:10.1016/j.agee.2012.07.009

Goulet F, Vinck D (2012) Innovation through withdrawal: contribution to a sociology of detachment. Rev Fr Sociol 53:117-146. doi:10.3917 /rfs.532.0195

Häni FJ, Boller EF, Keller S (1998) Natural regulation at the farm level. In: Pickett CH, Bugg RL (eds) Enhancing biological controlHabitat management to promote natural enemies of agricultural pests. University of California Press, Berkeley, pp 161-210
Havet A, Coquil X, Fiorelli JL, Gibon A, Martel G et al (2014) Review of livestock farmer adaptations to increase forages in crop rotations in western France. Agric Ecosyst Environ 90:120-127. doi:10.1016/j. agee.2014.01.009

Hendrickson JR, Hanson JD, Tanaka DL, Sassenrath G (2008) Principles of integrated agricultural systems: introduction to processes and definition. Renew Agric Food Syst 23:265-271. doi:10.1017 /S1742170507001718

Hermans F, Stuiver M, Beers PJ, Kok K (2013) The distribution of roles and functions for upscaling and outscaling innovations in agricultural innovation systems. Agric Syst 115:117-128. doi:10.1016/j. agsy.2012.09.006

Herrero M, Thornton PK, Notenbaert AM, Wood S et al (2010) Smart investments in sustainable food production: revisiting mixed croplivestock systems. Science 327:822-825. doi:10.1126 /science. 1183725

Horlings LG, Marsden TK (2011) Towards the real green revolution? Exploring the conceptual dimensions of a new ecological modernisation of agriculture that could "feed the world". Glob Environ Chang 21:441-452. doi:10.1016/j.gloenvcha.2011.01.004

Horrigan L, Lawrence RS, Walker P (2002) How sustainable agriculture can address the environmental and human health harms of industrial agriculture. Environ Health Perspect 110:445-456, http://www.ncbi. nlm.nih.gov/pmc/articles/PMC1240832/

Ingram J, Kirwan J (2011) Matching new entrants and retiring farmers through farm joint ventures: insights from the Fresh Start Initiative in Cornwall, UK. Land Use Policy 28:917-927. doi:10.1016/j. landusepol.2011.04.001

INRA (ed) (2007) Alimentation des bovins, ovins et caprins. Besoins des animaux - Valeur des aliments. Tables INRA 2007. Quae Editions, Paris

Jakku E, Thorburn PJ (2010) A conceptual framework for guiding the participatory development of agricultural decision support systems. Agric Syst 103:675-682. doi:10.1016/j.agsy.2010.08.007

Jordan NR, Slotterback CS, Cadieux KV et al (2011) TMDL implementation in agricultural landscapes: a communicative and systemic approach. Environ Manag 48:1-12. doi:10.1007/s00267-011-9647-y

Kennedy CM, Lonsdorf E, Neel MC, Williams NM et al (2013) A global quantitative synthesis of local and landscape effects on wild bee pollinators in agroecosystems. Ecol Lett 16:584-599. doi:10.1111 /ele. 12082

Kilpatrick S, Bell R, Falk I (2006) The role of group learning in building social capital. J Vocat Educ Train 51:129-144. doi:10.1080 $/ 13636829900200074$

Klerkx L, van Bommel S, Bos B, Holster H, Zwartkruis JV et al (2012) Design process outputs as boundary objects in agricultural innovation projects: functions and limitations. Agric Syst 113:39-49. doi:10.1016/j.agsy.2012.07.006

Koohafkan P, Altieri MA, Gimenez EH (2011) Green agriculture: foundations for biodiverse, resilient and productive agricultural systems. Int J Agric Sustain 10:61-75. doi:10.1080/14735903.2011.610206

Kremen C, Williams NM, Aizen MA, Gemmill-Herren B et al (2007) Pollination and other ecosystem services produced by mobile organisms: a conceptual framework for the effects of land-use change. Ecol Lett 10:299-314. doi:10.1111/j.1461-0248.2007.01018.x

Kremen C, Iles A, Bacon C (2012) Diversified farming systems: an agroecological, systems-based alternative to modern industrial agriculture. Ecol Soc 17:art44. doi:10.5751/ES-05103-170444

Kunrath TR, de Berranger C, Charrier X, Gastal F, de Faccio Carvalho PC et al (2015) How much do sod-based rotations reduce nitrate leaching in a cereal cropping system? Agric Water Manag 150:4656. doi:10.1016/j.agwat.2014.11.015

Landis DA, Wratten SD, Gurr GM (2000) Habitat management to conserve natural enemies of arthropod pests in agriculture. Ann Rev Entomol 45:175-201. doi:10.1146/annurev.ento.45.1.175 
Langer A, Hance T (2004) Enhancing parasitism of wheat aphids through apparent competition: a tool for biological control. Agric Ecosyst Environ 102:205-212. doi:10.1016/j.agee.2003.07.005

Ledgard S, Schils R, Eriksen J, Luo J (2009) Environmental impacts of grazed clover/grass pastures. Irish J Agric Food Res 48:209-226, Available at www.teagasc.ie/research/journalarchives/vol48no2 1209-226.pdf

Leeuwis C (1999) Science and integral design in agriculture and resource management. Identification of issues and organisation of the book. In: Leeuwis $\mathrm{C}$ (ed) Integral design: innovation in agriculture and resource management, Mansholt studies 15. Mansholt Institute, Wageningen, pp 1-11

Leeuwis C (2000) Reconceptualizing participation for sustainable rural development: towards a negotiation approach. Dev Chang 31:931959. doi:10.1111/1467-7660.00184

Lemaire G, Franzluebbers A, Carvalho PC de F, Dedieu B (2014) Integrated crop-livestock systems: strategies to achieve synergy between agricultural production and environmental quality. Agric Ecosyst Environ 190:4-8. doi:10.1016/j.agee.2013.08.009

Letourneau DK, Armbrecht I, Rivera BS, Lerma J et al (2011) Does plant diversity benefit agroecosystems? A synthetic review. Ecol Appl 21: 9-21. doi:10.1890/09-2026.1

Le Gal PY, Le Masson J, Bezuidenhout CN, Lagrange LF (2009) Coupled modelling of sugarcane supply planning and logistics as a management tool. Comput Electron Agric 68:168-177. doi:10.1016 jj.compag.2009.05.006

Le Gal PY, Bernard J, Moulin CH (2013) Supporting strategic thinking of smallholder dairy farmers using a whole farm simulation tool. Trop Anim Health Prod 45:1119-1129. doi:10.1007/s11250-012-0335-6

Le Roux R, Barbault J, Baudry J et al (2008) Agriculture et biodiversité, valoriser les synergies. Expertise scientifique collective, synthèse du rapport, INRA (in French). http://institut.inra.fr/Missions/Eclairerles-decisions/Expertises/Toutes-les-actualites/Agriculture-etbiodiversite

Lüscher G, Jeanneret P, Schneider MK, Turnbull LA et al (2014a) Responses of plants, earthworms, spiders and bees to geographic location, agricultural management and surrounding landscape in European arable fields. Agric Ecosyst Environ 186:124-134. doi:10.1016/j.agee.2014.01.020

Lüscher A, Mueller-Harvey I, Soussana JF, Rees RM, Peyraud JL (2014b) Potential of legume-based grassland-livestock systems in Europe: a review. Grass Forage Sci 69:206-228. doi:10.1111/gfs.12124

Lyon A, Bell MM, Gratton C, Jackson R (2011) Farming without a recipe: Wisconsin graziers and new directions for agricultural science. J Rural Stud 27:384-393. doi:10.1016/j.jrurstud.2011.04.002

Mace GM, Norris K, Fitter AH (2012) Biodiversity and ecosystem services: a multilayered relationship. Trends Ecol Evol 27:19-26. doi:10.1016/j.tree.2011.08.006

Macfarlane R (1998) Implementing agri-environment policy: a landscape ecology perspective. J Environ Plan Manag 41:575-596. doi:10.1080/09640569811461

Maes J, Paracchini ML, Zulian G, Dunbar MB, Alkemade R (2012) Synergies and trade-offs between ecosystem service supply, biodiversity, and habitat conservation status in Europe. Biol Conserv 155: 1-12. doi:10.1016/j.biocon.2012.06.016

Maletič M, Maletič D, Dahlgaard JJ et al (2014) Sustainability exploration and sustainability exploitation: from a literature review towards a conceptual framework. J Clean Prod 79:182-194. doi:10.1016/j. jclepro.2014.05.045

Martin G (2015) A conceptual framework to support adaptation of farming systems - development and application with Forage Rummy. Agric Syst 132:52-61. doi:10.1016/j.agsy.2014.08.013

Martin G, Duru M, Schellberg J, Ewert F (2012) Simulations of plant productivity are affected by modelling approaches of farm management. Agric Syst 109:25-34. doi:10.1016/j.agsy.2012.02.002
Martin G, Felten B, Duru M (2011) Forage rummy: a game to support the participatory design of adapted livestock systems. Environ Model Softw 26:1442-1453. doi:10.1016/j.envsoft.2011.08.013

Martin G, Martin-Clouaire R, Duru M (2013) Farming system design to feed the changing world. A review. Agron Sustain Dev 33:131-149. doi:10.1007/s13593-011-0075-4

Mediene S, Valantin-Morison M, Sarthou JP, de Tourdonnet S, Gosme M, Bertrand $M$ et al (2011) Agroecosystem management and biotic interactions: a review. Agron Sustain Dev 31:491-514. doi:10.1007/s13593-011-0009-1

Meiss H, Médiène S, Waldhardt R, Caneill J et al (2010) Perennial lucerne affects weed community trajectories in grain crop rotations. Weed Res 50:331-340. doi:10.1111/j.1365-3180.2010.00784.x

Menter, H, Kaaria S, Johnson N, Ashby J (2004) Scaling up. In: D Pachico, S Fujisaka (eds) Scaling up and out: achieving widespread impact through agricultural research. CIAT publication, 9-23

Mills J, Gibbon D, Ingram J, Reed M, Short C, Dwye J (2011) Organising collective action for effective environmental management and social learning in Wales. J Agric Educ Ext 17:69-83. doi:10.1080 /1389224X.2011.536356

Moraine M, Duru M, Nicholas P, Leterme P, Therond O (2014) Farming system design for innovative crop-livestock integration in Europe. Animal 8:1204-1217. doi:10.1017/S1751731114001189

Moraine M, Duru M, Therond O (2016a) A social-ecological framework for analyzing and designing crop-livestock systems from farm to territory levels. Renew Agr Food Syst. doi:10.1017 /S1742170515000526, available on CJO2016

Moraine M, Grimaldi J, Murgue C, Duru M, Therond O (2016b) Codesign and assessment of cropping systems for developing croplivestock integration at the territory level. Agric Syst 147:87-97. doi:10.1016/j.agsy.2016.06.002

Moraine M, Melac P, Ryschawy J, Duru M, Therond O (2016c) Participatory design and integrated assessment of collective croplivestock organic systems. In revision to Ecological indicators

Newig J, Haberl H, Pahl-Wostl C, Rotman DS (2008) Formalised and non-formalised methods in resource management-knowledge and social learning in participatory processes: an introduction. Syst Pract Action Res 21:381-387. doi:10.1007/s11213-008-9112-x

Noe E, Hugo FA (2015) Sustainable agriculture issues explained by differentiation and structural coupling using social systems analysis. Agron Sustain Dev 35:133-144. doi:10.1007/s13593-014-0243-4

Nuno A, Bunnefeld N, Milner-Gulland EJ (2014) Managing socialecological systems under uncertainty: implementation in the real world. Ecol Soc 19:52. doi:10.5751/ES-06490-190252

Pahl-Wostl C, Hare M (2004) Processes of social learning in integrated resources management. J Community Appl Soc Psychol 14:193206. doi:10.1002/casp.774

Paracchini ML, Pacini C, Jones MLM, Perez-Soba M (2011) An aggregation framework to link indicators associated with multifunctional land use to the stakeholder evaluation of policy options. Ecol Indic 11:71-80. doi:10.1016/j.ecolind.2009.04.006

Pecqueur B (2001) Qualité et développement territorial: l'hypothèse du panier de biens et de services territorialisés. Écon Rur 261:37-49, (in French) http://www.persee.fr/doc/ecoru_0013-0559_2001_ num_261_1_5217

Peyraud J-L, Taboada M, Delaby L (2014) Integrated crop and livestock systems in Western Europe and South America: a review. Eur J Agron 57:31-42

Poeplau C, Don A (2014) Carbon sequestration in agricultural soils via cultivation of cover crops - a meta-analysis. Agric Ecosyst Environ 200:33-41. doi:10.1016/j.agee.2014.10.024

Poeplau C, Aronsson H, Myrbeck A, Kätterer T (2015) Effect of perennial ryegrass cover crop on soil organic carbon stocks in southern Sweden. Geoderma Reg 4:126-133. doi:10.1016/j.geodrs.2015.01.004 
Power AG (2010) Ecosystem services and agriculture: tradeoffs and synergies. Philos Trans R Soc Lond B Biol Sci 365:2959-2971. doi:10.1098/rstb.2010.0143

Pretty J (2003) Social capital and the collective management of resources. Science 302:1912-1914. doi:10.1126/science.1090847

Puech C, Poggi S, Baudry J, Aviron S (2015) Do farming practices affect natural enemies at the landscape scale? Landsc Ecol 30:125-140. doi:10.1007/s10980-014-0103-2

Ratnadass A, Fernandes P, Avelino J, Habib R (2012) Plant species diversity for sustainable management of crop pests and diseases in agroecosystems: a review. Agron Sustain Dev 32:273-303. doi:10.1007/s13593-011-0022-4

Raudsepp-Hearne C, Peterson GD, Bennett EM (2010) Ecosystem service bundles for analyzing tradeoffs in diverse landscapes. Proc Natl Acad Sci U S A 107:5242-5247. doi:10.1073/pnas.0907284107

Robinson DA, Hockley N, Dominati E, Lebron I et al (2012) Natural capital, ecosystem services, and soil change: why soil science must embrace an ecosystems approach. Vadose Zone J 11:1. doi:10.2136 /vzj2011.0051

Rodriguez D, Cox H, deVoil P, Power B (2014) A participatory whole farm modelling approach to understand impacts and increase preparedness to climate change in Australia. Agric Syst 126:50-61. doi:10.1016/j.agsy.2013.04.003

Rodríguez-Ortega T, Oteros-Rozas E, Ripoll-Bosch R, Tichit $\mathrm{M}$ et al (2014) Applying the ecosystem services framework to pasturebased livestock farming systems in Europe. Animal 8:1361-1372. doi:10.1017/S1751731114000421

Röling NG (2002) Beyond the aggregation of individual preferences. Moving from multiple to distributed cognition in resource dilemmas. In: Leeuwis C, Pyburn R (eds) Wheel-barrows full of frogs. Social learning in rural resources management. Royal Van Gorcum, Assen, pp 25-47

Rusch A, Valantin-Morison M, Roger-Estrade J, Sarthou JP (2012) Using landscape indicators to predict high pest infestations and successful natural pest control at the regional scale. Landsc Urban Plan 105:6273. doi:10.1016/j.landurbplan.2011.11.021

Rusch A, Valantin-Morison M, Sarthou JP, Roger-Estrade J (2010) Biological control of insect pests in agroecosystems. Adv Agron 109:219-259. doi:10.1016/B978-0-12-385040-9.00006-2

Rusch A, Bommarco R, Jonsson M, Smith HG, Ekbom B (2013) Flow and stability of natural pest control services depend on complexity and crop rotation at the landscape scale. J Appl Ecol 50:345-354. doi:10.1111/1365-2664.12055

Russelle MP, Entz MH, Franzluebbers AJ (2007) Reconsidering integrated crop-livestock systems in North America. Agron J 99:325-334. doi:10.2134/agronj2006.0139

Ryschawy J, Choisis N, Choisis JP, Gibon A (2013) Paths to last in mixed crop-livestock farming: lessons from an assessment of farm trajectories of change. Animal 7:673-681. doi:10.1017/S1751731112002091

Ryschawy J, Choisis N, Choisis JP, Joannon A, Gibon A (2012) Mixed crop-livestock systems: an economic and environmental-friendly way of farming? Animal 6:1722-1730. doi:10.1017/S1751731112000675

Ryschawy J, Choisis JP, Joannon A, Gibon A, Le Gal PY (2014) Participative assessment of innovative technical scenarios for enhancing sustainability of French mixed crop-livestock farms. Agric Syst 129:1-8. doi:10.1016/j.agsy.2014.05.004

Ryschawy J, Moraine M, Martin G (2016a) Trade-offs among individual and collective performances related to crop-livestock integration among farms: a case study on crop-manure exchanges in France. Submitted to Agric Syst

Ryschawy J, Disenhaus C, Bertrand S, Allaire G et al (2016b) Assessing multiple goods and services derived from livestock farming on a nation-wide gradient. Submitted to Animal

Sarthou JP, Badoz A, Vaissière B, Chevallier A, Rusch A (2014) Local more than landscape parameters structure natural enemy communities during their overwintering in semi-natural habitats. Agric Ecosyst Environ 194:17-28. doi:10.1016/j.agee.2014.04.018

Scherr SJ, McNeely JA (2008) Biodiversity conservation and agricultural sustainability: towards a new paradigm of "ecoagriculture" landscapes. Philos Trans R Soc Lond B Biol Sci 363:477-494. doi:10.1098/rstb.2007.2165

Schewe RL, Stuart D (2014) Diversity in agricultural technology adoption: how are automatic milking systems used and to what end? Agric Hum Values 32:199-213. doi:10.1007/s10460-014-9542-2

Schipanski ME, Barbercheck M, Douglas MR, Finney DM et al (2014) A framework for evaluating ecosystem services provided by cover crops in agroecosystems. Agric Syst 125:12-22. doi:10.1016/j. agsy.2013.11.004

Schmitt A, Russelle MP, Randall GW, Lory JA (1999) Manure nitrogen crediting and management in the USA: survey of university faculty. J Prod Agric 12:419-422

Snapp SS, Swinton SM, Labarta R, Mutch D et al (2005) Evaluating cover crops for benefits, costs and performance within cropping system niches. Agron J 97:322-332. doi:10.2134/agronj2005.0322

Souchère V, King C, Dubreuill N, Lecomte-Morel V et al (2003) Grassland and crop trends: role of the European Union Common Agricultural Policy and consequences for runoff and soil erosion. Environ Sci Policy 6:7-16. doi:10.1016/S1462-9011(02)00121-1

Souchère V, Millair L, Echeverria J, Bousquet F et al (2010) Coconstructing with stakeholders a role-playing game to initiate collective management of erosive runoff risks at the watershed scale. Environ Model Softw 25:1359-1370. doi:10.1016/j. envsoft.2009.03.002

Soussana JF, Lemaire G (2014) Coupling carbon and nitrogen cycles for environmentally sustainable intensification of grasslands and croplivestock systems. Agric Ecosyst Environ 190:9-17. doi:10.1016/j. agee.2013.10.012

Soussana JF, Loiseau P, Vuichard N, Ceschia E et al (2004) Carbon cycling and sequestration opportunities in temperate grasslands. Soil Use Manag 20:219-230. doi:10.1111/j.1475-2743.2004. tb00362.x

Stallman HR (2011) Ecosystem services in agriculture: determining suitability for provision by collective management. Ecol Econ 71:131139. doi:10.1016/j.ecolecon.2011.08.016

Sulc RM, Tracy BF (2007) Integrated crop-livestock systems in the U.S. Corn Belt. Agron J 99:335-345. doi:10.2134/agronj2006.0086

Therond O, Hengsdijk H, Casellas E, Wallach D et al (2011) Using a cropping system model at regional scale: low-data approaches for crop management information and model calibration. Agric Ecosyst Environ 142:85-94. doi:10.1016/j.agee.2010.05.007

Thies C, Tscharntke T (1999) Landscape structure and biological control in agroecosystems. Science 285:893-895. doi:10.1126 /science.285.5429.893

Thorburn PJ, Jakku E, Webster AJ, Everingham YL (2011) Agricultural decision support systems facilitating co-learning: a case study on environmental impacts of sugarcane production. Int J Agric Sustain 9:322-333. doi:10.1080/14735903.2011.582359

Tilman D, Cassman KG, Matson PA, Naylor R, Polasky S (2002) Agricultural sustainability and intensive production practices. Nature 418:671-677. doi:10.1038/nature01014

Tonhasca A, Byrne DN (1994) The effects of crop diversification on herbivorous insects: a meta-analysis approach. Ecol Entomol 19: 239-244. doi:10.1111/j.1365-2311.1994.tb00415.x

Tonitto C, David MB, Drinkwater LE (2006) Replacing bare fallows with cover crops in fertilizer-intensive cropping systems: a meta-analysis of crop yield and N dynamics. Agric Ecosyst Environ 112:58-72. doi:10.1016/j.agee.2005.07.003

Tribouillois H, Cohan JP, Justes E (2015) Cover crop mixtures including legume produce ecosystem services of nitrate capture and green manuring: assessment combining experimentation and modelling. Plant Soil. doi:10.1007/s11104-015-2734-8, in press 
Tschumi M, Albrecht M, Entling MH, Jacot K (2015) High effectiveness of tailored flower strips in reducing pests and crop plant damage. Philos Trans R Soc Lond B Biol Sci 282:20151369. doi:10.1098 /rspb.2015.1369

Tuck SL, Winqvist C, Mota F, Ahnström J et al (2014) Land-use intensity and the effects of organic farming on biodiversity: a hierarchical meta-analysis. J Appl Ecol 51:746-755. doi:10.1111/13652664.12219

Van Ittersum MK, Ewert F, Heckelei T, Wery J et al (2008) Integrated assessment of agricultural systems - a component-based framework for the European Union (SEAMLESS). Agric Syst 96:150-165. doi:10.1016/j.agsy.2007.07.009

Van Mierlo B, Arkesteijn M, Leeuwis C (2010) Enhancing the reflexivity of system innovation projects with system analyses. Am J Eval 31: 143-161. doi:10.1177/1098214010366046

Véres A, Petit S, Conord C, Lavigne C (2013) Does landscape composition affect pest abundance and their control by natural enemies? A review. Agric Ecosyst Environ 166:110-117. doi:10.1016/j. agee.2011.05.027

Vertès F, Simon JC, Le Corre L, Decau ML (1997) Les flux d'azote au paturage. II. Etude des flux et de leurs effets sur le lessivage. Fourrages 151:263-280

Veysset P, Lherm M, Bébin D, Roulenc M (2014) Mixed crop-livestock farming systems: a sustainable way to produce beef? Commercial farms results, questions and perspectives. Animal 8:1218-1228. doi:10.1017/S1751731114000378
Vigne M, Peyraud JL, Lecomte P, Corson MS, Wilfart A (2013) Energy evaluation of contrasting dairy systems at multiple levels. J Environ Manag 129:44-53. doi:10.1016/j.jenvman.2013.05.015

Volk M, Ewert F (2011) Scaling methods in integrated assessment of agricultural systems - state-of-the-art and future directions. Agric Ecosyst Environ 142:1-5. doi:10.1016/j.agee.2010.10.014

Vounouki E, Rémy J (2009) Farmers' experiments, inventions and innovations: toward the emergence of a new heterodox productive model? Proceedings of the XXIII European Society for Rural Sociology congress, Vaasa, Finland, 17-21 August 2009

Wagner T, Posner J, Paine L (2008) Manure management on a township scale: using a land evaluation approach in Wisconsin. J Agric Food Environ Sci 2(1)

Wilkins RJ (2008) Eco-efficient approaches to land management: a case for increased integration of crop and animal production systems. Philos Trans R Soc Lond B Biol Sci 363:517-525. doi:10.1098 /rstb.2007.2167

Williams BK (2011) Adaptive management of natural resourcesframework and issues. J Environ Manag 92:1346-1353. doi:10.1016/j.jenvman.2010.10.041

Zhang W, Ricketts TH, Kremen C, Carney K, Swinton SM (2007) Ecosystem services and dis-services to agriculture. Ecol Econ 64: 253-260. doi:10.1016/j.ecolecon.2007.02.024

Zhu JC, Gantzer SH, Anderson SH, Alberts EE, Beuselinck PR (1989) Runoff, soil, and dissolved nutrient losses from no-till soybean with winter cover crops. Soil Sci Soc Am J 53:1210-1214. doi:10.2136 /sssaj1989.03615995005300040037x 